\title{
De wereld gaat aan beleid ten onder... : over beleidsfalen in de publieke sector en wat daar aan te doen
}

Citation for published version (APA):

van Mierlo, J. G. A. (2000). De wereld gaat aan beleid ten onder... : over beleidsfalen in de publieke sector en wat daar aan te doen. Universiteit Maastricht. https://doi.org/10.26481/spe.20000629hm

Document status and date:

Published: 29/06/2000

DOI:

10.26481/spe.20000629hm

Document Version:

Publisher's PDF, also known as Version of record

Please check the document version of this publication:

- A submitted manuscript is the version of the article upon submission and before peer-review. There can be important differences between the submitted version and the official published version of record.

People interested in the research are advised to contact the author for the final version of the publication, or visit the DOI to the publisher's website.

- The final author version and the galley proof are versions of the publication after peer review.

- The final published version features the final layout of the paper including the volume, issue and page numbers.

Link to publication

\footnotetext{
General rights rights.

- You may freely distribute the URL identifying the publication in the public portal. please follow below link for the End User Agreement:

www.umlib.nl/taverne-license

Take down policy

If you believe that this document breaches copyright please contact us at:

repository@maastrichtuniversity.nl

providing details and we will investigate your claim.
}

Copyright and moral rights for the publications made accessible in the public portal are retained by the authors and/or other copyright owners and it is a condition of accessing publications that users recognise and abide by the legal requirements associated with these

- Users may download and print one copy of any publication from the public portal for the purpose of private study or research.

- You may not further distribute the material or use it for any profit-making activity or commercial gain

If the publication is distributed under the terms of Article $25 \mathrm{fa}$ of the Dutch Copyright Act, indicated by the "Taverne" license above, 


\section{DE WERELD GAAT AAN BELEID TEN ONDER...}

Over Beleidsfalen in de Publieke Sector en Wat Daar aan te Doen 



\title{
DE WERELD GAAT AAN BELEID TEN ONDER...
}

\section{Over Beleidsfalen in de Publieke Sector en Wat Daar aan te Doen}

\author{
Dr J.G.A. van Mierlo
}

\section{INAUGURALE REDE}

in verkorte vorm uitgesproken

bij de aanvaarding van het ambt van

Bijzonder Hoogleraar Openbare Financiën

aan de Faculteit der Economische Wetenschappen en Bedriffskunde

van de Universiteit Maastricht op

Donderdag 29 juni 2000 
Alte rechten woorbehouden. Niets uit deze uitgave mag worden verweelwoudigd, opgeslagen in een geautomatiseed gegevensbestand, of openbaar gemaakt, in enige vorm of op enige wijze, hetzij elektronisch, mechanisch, door fotokopieen, opnamen, of enige andere manier, zonder vooratgaande schriftelijke toestemming wan de uitgever.

Voor zover het maken van kopieên uit deze uitgave is toegestan op grond van artikel $16 \mathrm{~b}$ Auteurswet 1912 jo. het Besluit van 20 juni 1974, Stb. 351, zoals gewijzigd bij het Bestuit van 23 augustus 1985, S6. 471, en artikel 17 Auteurswet 1912 , dient men de daarvoor verschuldigde wettelijke vergoedingen te voldoen aan de Stichting Reprorechi (Posthus 882, 1180 AW Amstelveen). Voor het overmemen van gedeelte(n) ujit deze uitgave in bloenlezingen, readers andere compilatiewerken (artike] 16 Auteurswet 1912) dient men zich tot de uitgever te wenden.

\section{CIP-GEGEVENS}

\section{Beleidsfalen}

De Wereld Gaat Aan Beleid Ten Onder.. Over beleidsfalen in de publieke sector en wal daar aan te doen/J.G.A. van Mierlo, Inaugurale rede, 29 juni 2000 , Universiteit Maastricht. -

Universitaire Pers Maastricht, Maastricht 2000.

ISBN 9052782865

NUG1 654,689

Trefw,: overheidsbeleid, beleidsfalen, openbare financien, welvaartstheorie.

Layout: J.G.A. van Mierio, m.m.v. D. Cloodt

Druk: Universitaire Pers Maastricht: 


\section{NHOUDSOPGAVE}

1. Openbare Financiën 7

2. Van Onderzok naar Belleid 9

3. De Methode wan 'Log Frame Analyse" 13

4. "Log Frame Analyse" wan Twee Beleidsprogramma"s 16

4.1. Infrastructuur en Rekening Rijden 16

4.2. Cannabisgebruik en Gedoogbeleid $\quad 22$

5. Beleidsfalen: Wat is er Mis? 28

6. Beleidsoplossingen: Wat kan er aan worden Gedaan? 1

7. Consequentives voor de Kerntaken van de Universiteit 33

$\begin{array}{ll}\text { Literatuur } & 39\end{array}$ 

Minheer de Rector Magnificus,

Zeer geworderde toehoorders,

\section{OPENBARE FINANCIEN}

Het vakgebied van de leeropdracht die ik vandaag met het uitspreken van deze rede aanvasurd, de Openbare Financiën, kent een lange geschiedenis. In het Nederlandse taalgebied stond het vakgebied voeger bekend als de Leer der Openbare Financièn. In het bekende leerboek wan C. Goedhart (1958 en 1975) uit de jaren vijftig wordt het wak op een normatieve manier beofend, als een vorm van toegepaste economie. Daarbij gaat het vooral om voorschriften voor politici en ambtenaren hoe om te gaan met 's-Rijksfinanciën, terwijl de feitelijke gedragingen van de overheid eigenlijk buiten beschouwing blijven. De positieve benadering van de publieke sector en van het overheidsgedrag in een gemengde economische orde, krijgt pas meer aandacht in de jaren zeventig, als inzichten wit de theoretische micro-economie, de welvaartstheorie en de zogeheten public choice-benadering niet alleen worden toegepast om marktgedrag te analyseren, maar ook economisch gedrag buiten de markt om, van politieke actoren in de publieke sector. Daamee wordit het vakgebied een gevestigd onderdeel wan de universitaire economische wetenschap, maar verliest het tezelfdertijd een gedeelte van zijn vroegere multidisciplimaire karakter van economie, politicologie en besturskunde. Deze ontwikkeling bereikt haar hoogtepunt met de toekenning van de Nobelprijs voor Economie aan James M. Buchanan, de grondlegger wan de public choice-benadering, in 1986. Deze ontwikkeling komt ook tot uiting in de veranderende benaming van het vakgebied (zie Musgrave en Musgrave, 1989; Stiglitz, 2000): in Nederland van openbare financiën naar economie van de publieke sector, international van "public finance' naar 'public economics'.

Waarom wordt deze leeropdracht dan misschien toch wat ouderwets omschreven als Openbare Financiën? Dat heeft drie redenen. Om te beginnen heeft Nederland een zekere traditie in het vakgebied, die teruggaat tot het einde van de negentiende eeuw als het bijvoorbeeld gaat om de economische analyse van belastingheffing (Cohen Stuart, zoals opgenomen in Musgrave and Peacock, 1967). Met de benaming Openbare Financiën wordt de historische continuiteit van deze traditie benadrukt. In de tweede plaats wordt hiermee het multidisciplinaire Karakter wan het vakgebied weer op de voorgrond geplatst. De economisch-wetenschappelijke analyse van het overheidsgedrag moet immers rekening houden met de politieke ongeving, waarin de overheid en de publieke sector in een democratische politieke orde functioneren. In de latste plasts heb ik zelf iets met de klassieke benaming van het vakgebied, ondat ik in 1976 als jongmatje in de economische wetenschap in Rotterdam in dit vakgebied ben begonnen bij de eerste voltijdsleerstoelhouder Openbare Financiën aan de Erasmus Universiteit, Dirk J. Wolfson. Die leerstoel was toen ondergebracht bij het Fiscaal-Economisch Institutut, warmee onder verwijzing nat mijn functie als opleidingsdirecteur Fiscale Economie aan deze universiteit de cirkel weer rond is. Openbare Financiën en Fiscale Economie hebben dus alles met elkar te maken, woor wie dit nog niet wist (zie bijwoorbeeld het fraale overzichtsartikel van de nestor van het vakgebied Richard Musgrave, 'A Brief History of Fiscal Doctrine', uit 1985).

Het vakgebied wordt ook onder de moderne benaming nog steeds onderwerdeeld in de wolgende vier deelgebieden: de owerheidsinkomsten (economie van de belastingheffing en van de sociate premieheffing), de overheidsuitgaven (uitgavenlleer), de overheidsorganisatie 
(instutionele analyse) en het overheidsbeleid (kosten baten analyse, beleidsanalyse en beleidsevaluatie). IK wh het met u vandaag hebben over dit laatsta onderdeel, de economische analyse van het overheidsbeleid. Meer in het bijzonder word de wragg behandeld, warom het zo valk misgat met overheidsbeleid en met beleidsprogramma's in de publieke sector (analyse) en wat daaraan zou kunnen worden gedaan (oplossingen). Zonder zich te bezondigen aan het populaire spel wan 'bureaucracy bashing" moet men toch beamen, dat weel beleidsprogramma's in de publicke sector niet tot het gewenste resultad leiden. Voortdurend "beleidsfallen", waarbij ik het dus niet heb over incidentele bedrifsongelukken of regelrechte rampen, schaad naturijk het vertrouwen in economisch-watenschappeljike onderbouwing van beleid, maar bedreigt uiteindeljk ook de legivimiteit wan de owerheid. Het eerste moet ons zorgen baren als econoom, het laatste moet ons dat doen als democrat.

\section{Betedisfaten wan beleidsprogramma's}

Veel beleidsprogramma's gaan gemankeerd aan een gebrekkige wetenschappelijke onderbouwing, ondanks de pretenties van het tegendeel, en in combinatie met een verkecrde sturingsflosofie leidt dit gebrek tot zogeheten 'beleidsfalen wan beleidsprogramma's'. Deze stwelling wordt un deze oratie op de volgende manier uitgewerkt. Na deze inleiding behandel ik eerst het waagstuk var wetenschappelijke onderbouwing van beleid. Daarna wordt ingegaan op de methodiek van de zogeheten "log frame analyse", waamee die wetenschappelijke onderbouwing kan worden geanalyseerd. Deze analysemethode wordt dan op twee concrete beleidsprogrannina"s toegepast. De resultaten van deze toepassing worden geanalyseend en met elkaar vergeleken, dit mede met het oog op generaliseerbare kennis over beleidsfalen in thet atgemeen. Vervolgens wordt gezocht naar oplossingen voor het probleem van beleidsfalen. Tenslotte worden enkele conclusies getrokken over de consequenties die dit allemaal heef voor de kemtaken wan de universiteit, per slot van rekening (ondanks de opmars van Internet) nog steeds de belangrijkste producent van wetenschap en kennis.

Onderzoek; of rumer geformuleerd wetenschap, en beleid zijn een klassiek begrippenparar (zie bijvoorbeeld Aquina, 1974). Wetenschappelijke kennis kan worden gebrukt ter onderbouwing van het overheidsbeleid. Dan hebben wij het over "science for policy". Beleid kan ook worden gebruikt ter versterking van de wetenschapsbeoefening. Dan is wetenschapsbeleid, ofwel 'science policy" aan de orde. Beleid en politiek kan ook onderdeel wan de wetenschapsbeoefening zijn (beleidsrelevantie van de wetenschap, maar ook politisering

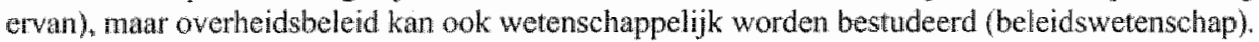
In schena 1 :

Schema 1. Typotogie wan Werenschap en Beleid

Wetenschap ter Ondersteuning whn Beleid

Wetenschap in het

Overheidsbellew

Politick/Beleid in de Wetenschap

Science for Policy

Politicisation of Science
Beleid ter Ondersteuning var de Wetenschap:

Science Policy

Policy Science 
Centraal in deze oratie statat de rol die wetenschappelijk onderzoek speelt in de onderbouwing van het overheidsbeleid ("science for policy"). Het overheidsbeleid word verondersteld beter to werken, narmate dat beleid meer en beter met de resultaten van wetenschappelijk onderzoek is onderbouwd. Sinds de jaren zeventig zien wij pogingen tot zulke wetenschappelijke onderbouwing; wij spreken dan over "rationalisering van beleid" (zie bijvoorbeeld Hoogerwert, 1993). Tezelfdertijd zien wij echter dat steeds meer overheidsbeleid ondanks deze verwetenschappeliking wan beleid, steeds minder effect sorteert. Deze opmerkelike paradox wordt hier aam een nadere beschouwing onderworpen.

Beleidsfalen is een klassiek thema in de beleidswetenschap. Jk herinner mij uit mijn eigen studietijd een boek als 'Great Planming Disasters' uit de jaren zeventig (Hall, 1981), terwijl meer recent het werk wan het Crisis Onderzoeks Team (COT) van de Leidse Universiteit steeds de andacht trekt. Uit deze school komt ook het boek "Understanding Policy Fiascoes' (Bovens and 't Hant, 1996). Over dergelijke spectaculaire beleidsfiasco's, rampen en crises gaat het vammiddag dus niet. Interessanter is het eventuele falen van grote, routinematige en zeer complexe beleidsprogramma's die al jaren worden uitgevoerd, maar waarvan ingewijden tooh stellig het gevoel hebben dat zij niet echt werken. Toch durf nienand dat hardop te zeggen en durft niemand dat ook echt hard te maken. Dergelijke tot standaardrapertoire geworden beleidspiogramma's hebben vaak ook een grote politiek-ideologische lading, waardoor zij in potentie misschien wel controversieel zijn, maar toch niet aan serieuze pogingen tot beleidsbeendiging worden onderworpen. Het is zelts denkbaar dat wordt aangetoond dat zulke programmats niet werken, maar desondanks toch worden voortgezet om ideologische of symbolische redenen. Twee van zulke beleidsprogramma"s zall ik zo aanstonds aanpakken.

Tot slot is beleidsfalen ook een klassiek thema in de public choice-benadering. In die benadering statat dit bekend als 'overheidsfallen' ('govermment faillure', zie Wolf, 1988 en 1993), in analogie met het thema van 'marktfalen' ('market failure') in de marktheorie. Onderdelen van deze theorie van overheidsfalen zullen nog aan de orde komen bij de verklaring van beleidsfalen van de twee betrokken beleidsprogramma's.

\section{VAN ONDERZOEK NAAR BELEID}

Ik kom nu toe aan het traject van wetenschappelijk onderzoek naar beleid. Daarvoor maken wij gebruik van (zij het elementaire) wetenschapsfilosofie. De logische structur van modern, empirisch georienteerd wetenschappelijk onderzoek wijkt fundamenteel af vilu die van modeme beleidsontwikkeling. Dat levert grote problemen op bij de wetenschappelijke onderbouwing van overheidsbeleid. Die problemen zijn overkomelijk wanneer zij worden onderkend in de beleidsvoming, maar wanneer dat niet het geval is dreigt het aforisme uit de titel van deze oratie werkelijkheid te worden.

\section{Catuale en finale theoric}

Laten wij dan eerst eens kijken naar de logische structuur van de weterischappelijke theorie (zie ook Kruijer, 1959 en 1986). In sociaal-wetenschappelijk onderzoek gaat het orn beschrijving. verklaring en voorspelling van bepaalde verschijnselen. Primaire doelstelling is het vinden van verklaringen voor die verschijnselen. Ofwel: in wetenschap gaat het on opsporing van oorzakgevolg relaties. Uitspraken over deze relaties zijn descriptief, in de zin van 'als..., dan..., "hoe..., des te.., enzovoorts. Waardoor wordt inflatie veroorzaakt, waardoor werkloosheid, waardoor economische groei, waardoor collectieve welvaart? Die oorzak-gevolg relaties kunnen 
vervolgens in zogeheten "causale theonieän" en "causale modellen" worden uitgewerkt. Onderscheiden kan ook worden in 'crasalle theoriemodellen' (op basis van deductieve theorievorning) wn 'causale veldmodellen' (op basis van cmpirisch onderzoek ter toetsing van die theotid). Uitgeschreven in schema 2 word gevolg $Y$, het te verklaren effect (ofwel de explanandum), werklaard door oorzatak X (ofwel de explanans):

\section{Schema 2. Cuusale Theorie}

\begin{tabular}{|c|c|c|}
\hline Oorzatak $X$ & $\rightarrow$ & Gewolg $\mathrm{X}$ \\
\hline (Causa) & & uentia) \\
\hline
\end{tabular}

De logische structur van de zogenoemde beleidstheorie" ziet er geheel anders uit. In beleid gaat het erom matschappelijke problemen op te lossen met behulp van schaarse middelen die collectief ter beschikking worden gesteld. Primaire doelstelling van beleid is de vermindering van het maatschappelijke probleem waarop het beleid is gericht. Het beleid wordt gehanteerd als middel, als instrument, om bepaalde doelstellingen te bewerkstelligen. Ofwel in beleid gaat het om de vormgewing van doel-middel relaties. Uitspraken over deze relaties zijn prescriptief: "als u dit wilt bereiken, moet u dat doen". Dat wordt ook wel "wetenschappelijk waardenrelativisme" genoend (zie Brecht, 1958). Hoe kan inflatie worden veminderd, hoe kan werkloosheid worden bestreden, hoe kan economische groei en collectieve welvaart worden bevorderd, enzovoorts. Deze doel-middel relaties kunnen in 'finale' of 'instrumentele theorieen' worden uitgewerkt. Zulke theorieén vormen het hart van een beleidsprogramma en worden ook wel beleidstheorieen" genoend. Uitgeschreven in schema 3 wordt beoogde doelstelling $Y^{*}$ bewerkstelligd door de inzet van mstrument $X^{*}$, het middel.

\section{Sohena 3. Finale Theorie}

Middel $X^{*} \quad \rightarrow \quad$ Doelstelling $Y^{*}$

(Instrumens)

(Finis)

Wetenschappelijke onderbouwing van overheidsbeleid vereist nu een vertaalslag van de causale wetenschappelijke theore nar de finale beleidstheorie. Wetenschappelijke onderbouwing wan beleid is gestugd als deze vertaalslag met succes wordt uitgevoerd. In dat geval berust de beleidstheorie immers niet meer op louter (speculatieve?) veronderstellingen (zie het oorspronkelijke artikel van Hoogerwerf over de Beleidstheorie, 1984), mar op in wetenschappelijk onderzoek vasigestelde oorzak-gevolg nelaties. Dit klinkt allemaal heel elementair, maar deze noodzakelijke vertalslag kan toch zeer gecompliceerd zijn. De kwaliteit wan de beleidstheorie die uit deze vertalslag resulteert, word in elk geval bepaald door de kwaliteit van de achterliggende wetenschappelijke theorie. De beleidstheorie kan per definitie ook niat beter zijn dan de achterliggende wetenschappelijke theorie, wel slechter.

De theorie van de beleidstheorie is in de jaren vijftig eigenlijk al de facto ontwikkeld door de econoon Jan Timbergen in zijn 'Economic Policy. Primciples and Design' (1967 $)$. 
Daarin wordi econometrische nodelbouw toegepast op de economische politiek van de overheid. In zijn econometrische modellen ter formulering wan de optimale economische politiek" maakt Tinbergen bijvoorbeeld een onderscheid tussen "instrument variables" (instrumentvariabelen) en "target wariables" (doelvariabelen). "Target variables" zijt afgeleid wan de Klassieke doelstellingen wan economische politiek (tn Nederland de "Gouden Vijhloek" genoemd), 'instrument variables' betreflen de beschikbare instrumenten van economische politiek, zoals conjunctumpolitiek, monetaire politiek en begrotingspolitick.

Econometrische modellen in de Timbergaanse tradicie zijn eigenlijk te beschouwen als modelmatige vertalingen van verbale beleidstheorieên wan de economische politiek. Dergehike modellen kunnen zeer complex zijn (ze de praktijk van het beleidsonderzoek van het Central. Planbureau!), maar hebben alle de logische grondwom van de "multiple regressievergelijking" (zie ook Van Mierlo, 1989), zoals weergegeven in schema 4:

Schema 4. Multiple regressievergelikng als logische grondworm van de econometrische beteidsheorie

$$
\begin{aligned}
& \mathrm{Y}=\mathrm{B}_{1} \mathrm{X}_{1}+\mathrm{B}_{2} \mathrm{X}_{2}+\mathrm{B}_{3} \mathrm{X}_{3}+\mathrm{B}_{4} \mathrm{X}_{4}+\ldots+\mathrm{B}_{13} \mathrm{X}_{\mathrm{in}}+\mathrm{c}+\mathrm{E} \\
& \mathrm{Y} \quad \text { a afhankelijke variabele } \\
& \mathrm{X}_{1} \ldots \mathrm{X}_{\mathrm{n}} \quad \text { = onafhankelijke variabelen } \\
& \mathrm{B}_{\mathrm{i}} \ldots \mathrm{B}_{\text {เ }}=\text { beta-coëfficięnten } \\
& \text { c } \quad=\text { constante } \\
& \varepsilon \quad=\text { storingsterm }
\end{aligned}
$$

De kwaliteit van de beleidstheorie wordt dus bepaald door tenminste twee deterninanten: ten eerste door de kwaliteit van de onderliggende wetenschappelijke theorie, en ten weede door de kwalliteit van de vertaalslag van de wetenschappelijke theorie naar de beleidstheorie.

\section{Intern-methodologische problemen}

Aan de hand van de multiple regressievergelijking in schema 4 kunnen wij eerst de infernmethodologische problemen inventariseren die abrenk doen aan de kwaliteít van de wetenschappelijke theorie. Ten eerste zijn er problemen die te maken hebben met het causale verband zelf ussen de onafhankelijke variabelen aan de rechter zijde van het =-1sken in de vergeliking, en de athankelike variabele links van het =-teken. Hoe groot is de totale verklaarde variantie van de afhankelijke variabele links en hoe is dat verdeeld over de verklarende variabelen rechts in de vergelijking (de B-coefficiënten)? Binnen welk betrouwbaratheidsinferwal en bij welk significantienivear? En prealabel an dit alles. hoe stat het eigenlijk mat de (theoretische) geldigheid (of "validiteit") van de gebruikte empirische variabelen in het model?

Ten tweede problemen van multi-causaliteit en mult-collineariteit. Zijn de onathankelijke wariabelen in het model well echt onafluankelijk van elkaar, of bestrat daartussen ook een onderling verband? Hoe gaan we dan om met eventuele multïcollineariteit en autoregressie? En wat als het tweezijdige (wederkerige) relaties betroft tussen de onafhankelijke variabelen? En hoe worden eventuele terugkoppelingsprocessen ingebouwd in het cutsale model?

Voorts zijn er stabiliteitsproblemen in het model. Te denken valt bijvoorbeeld aan zogeheten pad-athankelijkheid ("path dependency"). Eenmaal gemaakte keuzen in het verleden beperken de speelrumte voor keuzes in het heden, ofwel in modeltermen: cenmaal berikte variabelewaarden in het verleden beperken de variatiebreedte van de variabelewaarden in het 
heden. Dat is bijvoorbeeld het geval bij onomkeerbare processen in het milieuvrasgstuk (uituting van grondstoffen, kimadweranderingen). En wat als het blijkt te gaan om een centrifugaal madel (steeds grotere wawnen van de afhankelijke variabele, waardoor het model als het ware "explodeert"), in plaats van een centripetall model (steeds kleinere waarden daarvan, wardoor het model "implodeert") of een dynamisch algemeen evenwichtsmodel (walan warden centreren rond een bepaald bereik)? Zie daarvoor ook uitgebreid de vroege analyse van Tinbergen (1943).

Ten vierde is ex het problewm van intervenièrende variabelen tussen onafhankelije en afhankelijke wariabelen. Een ogenschijnlijk caussal verband tussen onathankeljke en afhankelike variabelen kan feitelijk va een derde, interveniërende (groep van) variabele(n) lopen. De eventuele aanwezigheid van interveniërende variabelen kan met behulp van zogeheten "alaboratie' worden opgespoord, maar dan moet men vooraf al wel enig vermoeden hebben van het bestaan en de aard ervan. Bekend is het voorbeeld van het ogenschijnlijke verband tussen het aantal ootevars en het aantal geboorten, die beide feitelijk worden verklaard door het lenteseizoen. Het bestan van intervenierende variabelen leidt tot zeer complexe, meerlagige causale modellen en dus dito beleidsmodellen, zoals wij nog zullen zien.

In de vijfde plaats komen wij een oude bekende wit de economische wetenschap tegen, de beruchte "ceteris paribus-clausule". Met name in partiele evenwichtsmodellen wordit deze clausule gehanteerd. Een voorbeeld: onder de veronderstelling dat alle overige (relevante) omstandigheden hetzelfde blijven, leidt een prijsverhoging van benzine als gevolg van ecologische belastingheffing, tot een afzetdaling. Probleem is evenwel dat in de beleidspraktijk ceteris vaak niet paribus is of gemaakt kan worden. Er is in de praktijk immers niet sprake van een gecontroleerd laboratoriumexperiment, maar wan moeilijk controleerbare en beheersbare veldexperimenten. Daarbij is de bekende "before-after" methode met controlegroepen en dubbelblindheid vaak niet mogelijk. Dus moeten de ceteris-condities eigenlijk in het model zelf worden opgenomen, in plaats van weggedefinieerd (in vaktemen: geëndogeniseerd in plats van exogeen gehouden).

Dan is er tot slot het in de economische wetenschap minstens zo benchte probleem van de elasticiteiten. De analyse daarvan begint met inkomens- en substitutie-effecten van prijsveranderingen, on via prijselasticiteiten en inkomenselasticiteiten van vraag en aanbod uit te komen op kruiselingse prijselasticiteiten tussen tenminste twee markten, waardoor complementarteit of substitutie tussen twee goederen zichtbaar wordt gemaakt. De microeconomische prijstheorie levert weliswar een complete gereedschapkist voor de grafische en wiskundige andlyse hiervan, maar uiteindelijk draait het toch om de empinische kwantificeerbaarheid wan dit soot effecten en dan bljkt er toch schrikbarend weing hard empirisch materiaal voorhanden te zijn. Voor zover onderzoeksdata beschikbaar zijn, blijken elasticiteiten te variëren mar groepen consumenten/producenten, goederen en markten, economische orde en ontwikkelingsniveau, alsmede in de tijd. Bovendien varièren zij ook nog eens naar specifieke locatie op de vraag- en aabodcurves (punt- versus boog- of segmentelasticiteit). Kortom, deze parameters zijn niet stabiel en dat is niet alleen opmerkelijk, maar ook heel vervelend. Hoe belangrijk dit probleem is voor de beleidspraktijk zal hieronder nog blijken.

\section{Extern-methodologische problemen}

De tweede groep van problemen heef betrekking op de vertaalshg van de causale wetenschappelijke theorie naar de finaal-instrumentele beleidstheorie. Zoals gezegd zal de kwaliteit van de resulterende beleidstheorie in eerste instantie athangen van de kwaliteit van de onderliggende wetenschapelijke theorie. Zijn er in die onderliggende causale theorie zwakke schakels, lacunes en wat dies meer zij van alle bovengenoemde intern-methodologische 
problemen, dan leidt de kwalitent van de beleidstheorie daar onherroepelik onder. Marar zelts als de onderliggende causale theorie in orde is, kunnen er weer andere problemen ontstaan in de vertallslag naar de beleidstheorie.

Die categorie van problemen noem ik etrem-methodologische problewen. Niet alle oorzaken in het causale model kunnen altijd worden vertaald naar instrumenten in het finale model, en milet alle gevolgen in het causale model kwnen altijd worden vertaald in doelstellingen in het finale model. Immers, niet alle doelstellingen zijn geoorloofd, niet thle doelstellingen zullen worden gelegitimeerd in het beleidsproces. Voor de econoom zijn doelstellingen gegeven (nog eens fraa verwoord door Wolfson in zijn afscheidscollege, 1998), maar voor beleidsmakers nu juist niet! Bovendien heiligt het doel niet altijd de middelen: grenzen worden gesteld door het "Proportionaliteitsbeginsel" (evenredigheid tussen doel en middelen) en het "Kantaanse principe" (intrinsicke waarden gaan boven instrumentele). Voorts zijn niet alle oorzaken manipuleerbaar, en dus niet in hanteerbare beleidsinstrumenten om te zetten. In dat geval is er voor het betrokken beleidsprobleem misschien geen oplossing. Dat heeft consequenties voor de probleemdefinitie. Dan dringt zich de vraag op: geen oplossing, geen probleem? Ook blijken veel beleidstheorieën ook nog assumpties te bewatten die niet zijn terug te voeren op het onderliggende causale nnodel. Tenslotte bewatten zij nogal eens waarde-oordelen die zich niet beperken tot de vaststelling van de beleidsdoelstellingen (die kunnen worden afgeleid uit de "maatschappelijke welvartsfunctie", zoals vastgelegd in het beleidsproces), maar ook voorkomen in andere schakels van de beleidstheorie.

Als wij de hierboven geschetste methodologische problemen in het traject van onderzoek naar beleid overzien, lijkt het een Godswonder dat er sowieso nog beleidsprogramma's zijn die wel werken. Maar misschien is er sprake van optische vertekening. Succesvolle beleidsprogramma's trekken nu eenmaal minder de aandacht dan falende programma's: goed nieuws is geen nieuws, alleen slecht nienws is nieuws. Laten wij m eens bezien op welke wijze het succes of falen van beleidsprogramma's kan worden geanalyseerd.

\section{DE METHODE VAN 'LOG FRAME ANALYSE'}

Beleidsevaluatie is een onderdeel van beleidsanalyse. De onder economen zo bekende Maatschappelijke Kosten-Baten Analyse (MKBA, zie bijvoorbeeld Zerbe and Dively, 1994) is een specifteke variant van beleidsevaluate. Beleidsevaluatic is het logische sluitstuk van beleidsanalyse. In een beleidsevaluatie word een beleidsprogramma geevalueerd, dat wil zeggen beoordeeld op criterig als inteme consistentie, alsmede externe effectiviteit (werkt lhet, ofwel worden de beoogde beleidsdoelstellingen bereikt?) en efficièntie (tegen de minste kosten, ofwel worden de beleidsdoelstellingen bereikt op de meest doelmatige manier?).

Een andere vorm van beleidsevaluatie betreft de reconstructie van de beleidstheorie van het betrokken beleidsprogramma. Die reconstructie kan vooraf plats hebben, whara ook achteraf (apriori versus aposteriori). De zogeheten 'Logical Framework Approach' (LFA), voortatan afgekort tot 'log frame analyse', is een geavanceerde methode van reconstructie van de beleidstheorie (zie EC, 1993; Leeaw, 1999). Deze methode heeft de volgende uitgangspunten:

1. Reconstructie en beoordeling van de onderliggende programmalogica is noodzakelijk om kennis en inzicht te verkrijgen in de toekomstige mogelijkheden van het beleidsprogramma. Hoe steekhoudender de premissen en assumpties van een beleidsprogranma, des te groter de kans op succes van dat programma. 
2. Deze onderliggende programmalogica moet worden gereconstrueerd, ondat deze gewoonlijk door beleidsmakers, politici en ambtenaren in het beleidsprogramma niet expliciet wordt geformuleerd.

3. Er is geen apriori bewijs dat de onderliggende assumpties en premissen (of zo u will: de beleidstheorie) geldig zijn, d.w.z. logisch consistent en empirisch correct.

De 'Iog frame'-benadering biedt een gereedschapkist voor de planning, het ontwerp, de uitvoering en de evaluatie van projecten. 'Log frames" bieden een gestructureerde en logische benadering om prioriteiten te stellen en beoogde resultaten en projectactiviteiten vast te stellen. LFA's worden inmiddels door tal van internationale instellingen gebruikt, bijvoorbeeld de Europese Commissic ('EU Project Cycle Management'), US AID en onder ontwikkelingshulporganisaties, de Wereldbank en het CGIAR (Consultative Group on International Agricultural Research'). De geschiedenis ervan gaat terug tot de jaren zestig (Solem, 1987). 'Log frame analyse' is een poging on op een geintegreerde, systematische en nauwkeurige manier na te denken over:

a. projectdoelstellingen;

b. causale verbanden tussen verschillende projectniveaus;

c. veronderstellingen over andere factoren, welke nodig zijin om geldige verbanden te leggen tussen deze verschillende niveaus;

d. de beoordelingsmethode ten aanzien van de mate, waarin de verschillende niveaus van projecidoelstellingen zijn verwezenlijkt.

Onderdeel a, de hiërarchie van projectdoelstellingen, vormt de kern van de analyse. De andere onderdelen zijn daarvan cen operationalisatie en rationalisatie. Onderdelen b en $c$ vormen de verticale logica van de resulterende matrix, onderdeel $d$ betreft de horizontale logica.

De 'log frame analyse' bestaat uit de volgende vier stappen:

\section{Stap I. Analyseer het probleem en ontwikkel een probleemboam}

De analyse begint met een probleemanalyse. Daarin worden de belangrijkste problemen geanalyseerd en wordt een probleemboom ontwikkeld met behulp van een oorzaak-gevolg analyse. Probleemidentificatie heeft plaats met behulp van brainstorm-technieken. Daarin herkennen wij overigens de Maastrichtse onderwijstilosofie van Probleem-Gestuurd Onderwijs (PGO).

\section{Stap 2. Doelstellivigenanalyse}

De probleemboom wordt dan vertald in een doelstellingenboom. Dit is de al genoemde vertals lag van de causale naar de finalle theorie. De doelstellingenboom is te beschouwen als het (positieve) spiegelbeeld van de probleemboom.

\section{Stap 3. Toetsing van de logica van de probleemboom}

Deze derde stap kan op verschillende manieren worden ingevuld.

Stap 3.1. Intentiestructuriranalyse

Intentiestructur -analyse resulteet in een doel-middeten diagram warin waanden en normen, doelstellingen en gedetailleede activiteten van organisatio, programma- of projectonderdalen zijn ondergebracht. De logica van de boom wordt onderzocht door an de bovenkant van de hierarchie te beginmen en te vragen hoe elk niveau wan de hiërarchie moet worden verwezenlijkt, envof door aan de onderkant wan die hierarchie te vragen warom die doelstelling wordt nagestreefd en die activiteit wordt ontplooid. 
Stap 3.2. Krachenved-analyse

Deze methode wordt gebruikt om een lijst wart factoren op te stellen die de verwezwhliking wan projectdoelstellingen bevorderen of belemmeren. Krachemweld-analyse levent een model op dat de beleidsdeelnemers aanmoedigt om:

-kenmerken van de bestande situatie te onderzoeken:

-positieve en negatieve krachten te inventariseren die wan invloed zijn op de doelverwezenlijking;

-methoden te bedenken die pasitieve krachten versterken en negatieve krachten afzwakken:

\section{Stap 3. 3. SWOT-analyse}

SwOT ("Strengths, Weaknesses, Opportunities and Threats") is een veelgebruikte methode on de beperkingen an mogelijkheden van eer project te verkannen. Het kan worden gebrukt on de wolledigheid van een doelstelling te onderzoeken. Sterke en zwakke kanten hebben betrekking op de "binnenkant" van eeri project: de inherente projecteigenschappen; nogelijkeden en bedreigingen verwizen naar de "buitenkani" ervan: hun invloed op de maie wan doelbereiking van het project.

\section{Stap 4. Assumptie-analyse}

De laatste stap betreft de analyse van assumpties. Specificatie van assumpties is nodig om de externe factoren te iddentificeren die van invloed zijn op het succes of falen van een project. Wanneer assumpties eenmaal zijn geidentificeerd, worden zij geformuleerd in termen van de gewenste situatie. De opgespoorde assumpties worden in een zogeheten "assumptic-algoritme" ondergebracht. Een woorbeeld daarvan wordt gepresenteerd in schema 5.

\section{Sohema 5. Assumptie-algoritme}

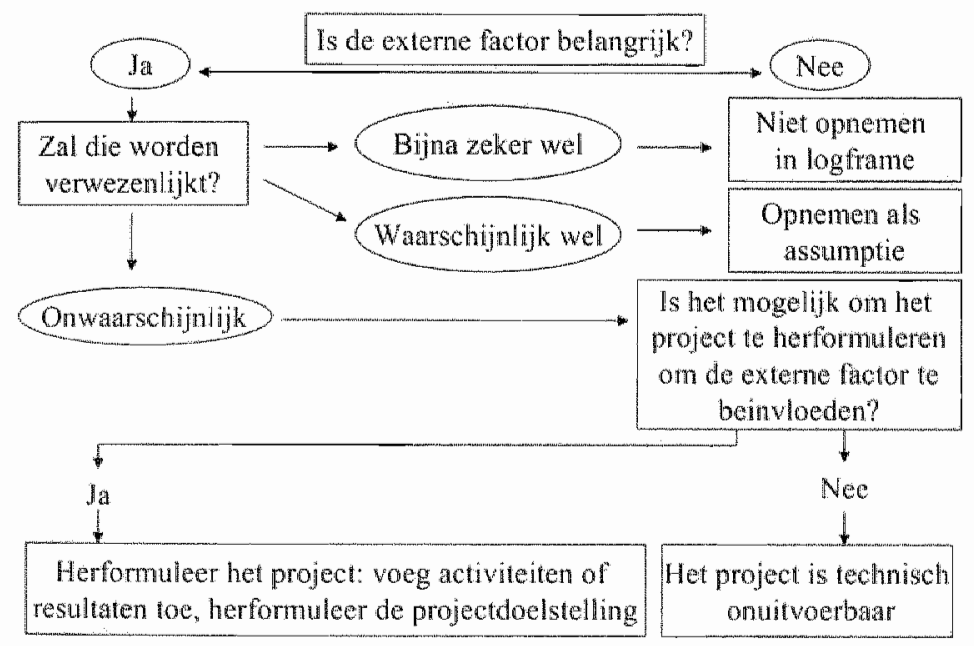

Soms zujin er nog 'vistregels' ten aanzien van de manier, warop een LFA in de praktijk ter hand wordt genomen (dit gebeurt meestal in "workshops"). Daarin worden bijvoorbeeld suggesties gedaan over het aantal deelnemers en hun selectie, de manier waarop problemen worden geanalyseerd en de manier waarop de rapportage wordt voorbereid en gepresenteen. 
Frans Leew (1999), een atoriteit op het gebied van LFA, geeft nog het volgende kritische commentaar bij de "log frame analyse" als methode van beleidsanalyse:

-waroni de assumpte-analyse word beperkt tot exteme factoren buiten het bereik van projecten., is riet dwidelik. Inteme factoren zijn minstens zo belangrijk,

-ondudelik is ook in welke mate interne "administratieve en beheersmatige" kernis die over extente factoren aanwezig is, in beschowwing wordt genomen, beoordeeld wordt en wordt afgehandeld;

-onduidelijk is verder of geidentificeerde assumpties nu wel of niet worden beoordeeld in termen van thun empirische inhoud of hun logische consistentie. Als dat niet gebeurt kan men zich afvagen. wat de toegevoegde warde is wan de speurtocht naar assumpties:

-in een kritisch overzicht van Gasper (1997) over de voors en tegens van LFA worden nog andere zwakke punten genoemd. Bijvoorbeeld de mogelijkheid dat 'log frame analyse' verwordt tot "lock framewortio analyse", dat wil zeggen het gevaar van rigide toepassing van LFA en het gevalu, dat de invalghoek verschuft van identificatie wan en discussie over inhoudelijke assumpties naar een over zuiver procedurele en administratieve. Dat wordt ook wel 'box filling" genoend (Gasper, 1997: p. 31);

-tensiotte moet worden gewezen op het risico van verwaarlozing of onderschatting van onbedoelde neveneffecten en van belemmering van beleidsinnovaties. In de woorden van Gasper (1997: $p .31$ ) "LFA's (may) become a fetish, rather than a help".

"To: zover deze uiteenzetting over de LFA-methode. Het wordt wijd dat wij deze methode eens gan toepassen op wee concrete beleidsprogramma's.

\section{4. "LOG FRAME ANALYSE" VAN TWEE BELEIDSPROGRAMMA'S}

"Log frane analyses" van concrete beleidsprogramma's blijken in de praktijk van beleidsonderzoek gemakkelijk uit te dijen tot uitgebreide onderzoeksprojecten, zo leert de ervaring. Dat heeft te maken met de toenemende complexiteit van beleidsprogramma's. Het gat immers in beleidsprogramina's per defintie niet meer om afzonderlijke projecten, maar om een geintegreerd samenstel van samenhangende projecten waamee een complex beleidsprobleem wordt aangepakt. Op deze plaats moet ik mij beperken tot presentatie wan twee vingeroefeningen in 'log frame analyse', maar ik hoop u hiermee te laten zien wat men met deze methode kan doen. Ik heb voor deze vingeroefeningen de volgende twee beleidsprogramma's uitgezocht:

1. "rekening grijen' in het beleidsveld van de infrastructuru;

2. "gedoogbeleid" in het beleidsveld van het cannabisgebruik.

Beide beleidsprogramma's zinn niet alleen technisch complex, maar ook politiekmatschappelijk controversicel in Nederland, reden genoeg om er eens kritisch naar te kijken met behulp van een LFA.

\subsection{Infrastructuar en Rekening Rijden}

Ruimtelijke infliastructur is volgens de 'theorie van de collectieve goederen' (zie Wolfson, 1988) een zogeheten 'club good' of 'toll good' (zie ook Buchanan, 1968). Dergelijke goederen worden gekenmerkt door de technische uitsluitbaarheid van consumptie an de ene kant, maar ook nontivaliteit in de consumptie aan de andere kant. Zolang de capaciteit van de weg groter is dan het feitelijk gebruik ervan, zijn de marginale kosten wan toetreding van een extra automobilist gelijk am nul. Als gevolg wan technische ondeelbaatheid zinn er alleen vaste kosten, die leiden tot dalende gemiddelde kosten (zie Oort, 1958). Toepassing van de gouden imarginale 
kosten-regel' uit de welvartstheorie leidt dan tot de conchasie, dat de toegang fot die wag nief aan een prijs moet worden gebonden, dus gratis moel zijn. De waste kosten wan do weg (anleg en onderhoud) dienen op een andere manier te worden gefinancierd, bijvoobeeld bekostiging unt de algemene middelen (die uil belastingheffing worden gevuld). Voor de infrastructur als "chb" of "toll good" geldt dan, dat er technisch wel een prijs kan worden gevraagd, maar dat dat economisch onverstandig is zolang ar althans geen schaarste is (zie ook Oort, 1959).

Het verhaal wordt anders als er wel sprake is van schatste. Dat is het geval als de capaciteitsgrens van de weg wordt genaderd. Ex treedt dan vertraging en filewoming op. Er tw sprake van zogeheten 'congestiekosten': opeens hebben de automobilisten op de weg last wan elkat en van elke nieuwe automobilist op die weg. Congestiekosten rijn een specifiek geval wan (negatieve) 'externe effecten': zij werken immers buiten de markt om, zijn niet in de prijs verrekend, en beinvloeden de consumptiemogelijkheden van de overige automobilisten. Er ontstat dan schaarste, in dit geval wan wegcapaciteit. De marginalle congestiekosten dienen dan te worden gehanteerd als indicator voor de toegangsprijs tot die weg, zo leert ons de welvartstheorie. Daardoor wordt de vraag gereguleerd, omdat alleen die automobilisten nog van de weg gebruk zullen maken, voor wie de toegangsprijs tenminste gelijk is an hun grensnut wan het gebruik van die weg. Automobilisten voor wie de toegangsprijs te hoog wordt in verhouding tot hun grensnut, zullen de weg verlaten of links laten liggen en naar altematieven gaan zoeken (substitutie). De kunst is nu om de toegangsprijs van de weg zo hoog te maken, dat doon de toetreding van de laatste automobilist de capaciteitsgrens van de weg zo ongeveer word: bereikt, maar niet zo hoog, dat te veel automobilisten de weg vetaten of mijden en er dus onbenutte capaciteit ontstaat door te veel vraaguitval. Dit is een prachtig optimalisatievraagstuk voor het vraagmanagement wan de wegbeheerder en leidt tot bijwoorbeeld prifsdifferentiatie voor de automobilist, afhankelijk van het variabele gebruik van de weg in de tijd. Dit is ook de rationale voor spits-dal tarieven. Daarmee komen wij uit op het instrument van 'road pricing" uit de welvaartstheorie.

Technieken van 'road pricing', ofwel "rekening rijden', worden reeds langer gebrukt in verstedelijkte gebieden ("metropolitan areas") in het buitenland, bijvoorbeeld Hong Kong en Singapore. Daarbij helpt de technologie een handje: zonder geavanceerde ICT -hulpmiddelen zou de uitvoering van rekening rijden meer kosten dan het opbrengt aan tolgelden. Genoemde varianten van rekening rijden hebben ook gefungeerd als "lichtend voorbeeld" voor de Nederlandse discussie, die al zo"n tien jaar word" gevoerd. Vooral de Randstad dreigt te worden getroffen door een verkeersinfarct als gevolg van excessief toenemende congestiekosten van het autoverkeer. De discussie wordt vooral gekleurd door politieke emoties on economische belangenstrijd. Ondanks taaie politicke tegenstand en heftig verzet van georganiseerde belangengroepen in de samenleving (ANWB, werkgeversorganisaties, organisaties van beroepsvervoerders en verladers), is verantwoordelijk Minister Netelenbos er dit voorjaa in geslaagd een integraal plan op tafel te leggen, warin wordi geprobeerd het dreigend verkeersinfarct in de Randstad te voorkonien. Dat plan is vervati in de beleidsnotitie 'BereikbaarheidsOffensief Randstad', ofwel BOR (elke gelijkenis met de gelijknamige Wolf uit de Fabeltjeskrant berust natuurlijk op toeval!), van het Ministerie van Verkeer en Waterstaat (maart 2000).

Doel van het Bereikbaarheidsoffenstef is een bereikbare Randstad. De Rijksowerheid trekt hiervoot to 2010 tien miljard gulden extra uit. Dit bedrag is bestend voor een uitgebreid pakket aan maatregelen: investeringen in nieuwe infrastructuur, beter gebruik wan bestaande wegen en spoorwegen, aampak van verkeersknelpunten en beter openbaar varvoer. lin de Beleidsnotitie wordt gesteld, dat de files in de Randstad niet door ểm enkele maatregel worden opgelost, niet door Randstadrail (een worm van 'light rail'), niet door betalstroken, niet door "car 
poolen': Marar in een evenwichtige combinatie zullen de matregelen wél optimaal bijdragen aan een bereikbare Randstad. Het Ministerie schijh un de Beleidsnotitie, hierover in gesprek te willen bliwen met de partiers in de regio en met het bedrijfsleven. Dat is mooi. In de notitie wordt dieper ingegaari op spitstarieven, mobilitetsmanagenent, wegenbelasting en regionale mobiliteitsfondsen. Dat s nog mooier. Maar zal dit offensief ook werken?

\section{Van probleemboon noar doelstellingenboom}

Laten wij er het net behulp van "log frame analyse' er eens wat nawwkeuriger narr kijken. Wij beginnen met een reconstructie van de probleemboom in het BOR (zie schema 6).

\section{Sehend 6. Probleamboom in her $B O R$}

Dreigend Verkeersinfaret in de Randstad

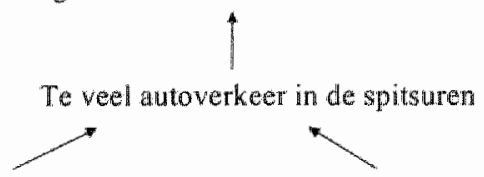

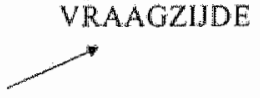

Te veel wraag naar bestande verketswegen<smiles>C[13CH3]</smiles>

Te lage prijs voor het "gebruik van de wege"
Onderbenutting van capaciteit van verkeerswegen

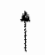

Te weinig creatief gebruik van bestaande capaciteit verkeerswegen

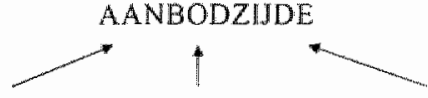

Te weimig capaciteil Te weinig capaciteit van bestaande verkeerswegen

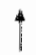

Te weinig capaciteitsuitbreiding verkeerswegen c.q. onderbenutting Openbaar verwoer

Te weinig creatief gebnuik c.q. te weinig uitbreiding Openbaar Vervoer

Hierbij hoort de volgende toelichting. Het dreigend werkeersinfarct in de Randstad is het hoofdprobleen. Dat wordt veroorzaakt door het tussemprobleem: te veel autoverkeer in de spitsuren. De ooraken darvan kunnen worden onderscheiden in wragfactoren en aanbodactoren. Aan de vraggzijde gaat het on te veel vraag naar bestaande wegcapaciteit. Aan de aanbodzijde spelen drie factoren een rol: onderbenutting van bestaande wegcapaciteit, te weinig wegcapaciteit, en te weinig benutting en capaciteit van openbaar vervoer. In de onderste regel van schema 6 vinden wij de echte oorzaken van elk van deze vier problemen terug. Dan gaat het om respectievelijk een tage lagris van de weg, te weinig creatief gebruik en te weinig uitbreiding wan wegcapaciteit, en te weinig creatief gebruik en te weinig nitbreiding wan openbaar vervoet.

De vertalslag naar de beleidstheorie in het BOR resulteert in de volgende doelstelingenboom (schenta 7). 


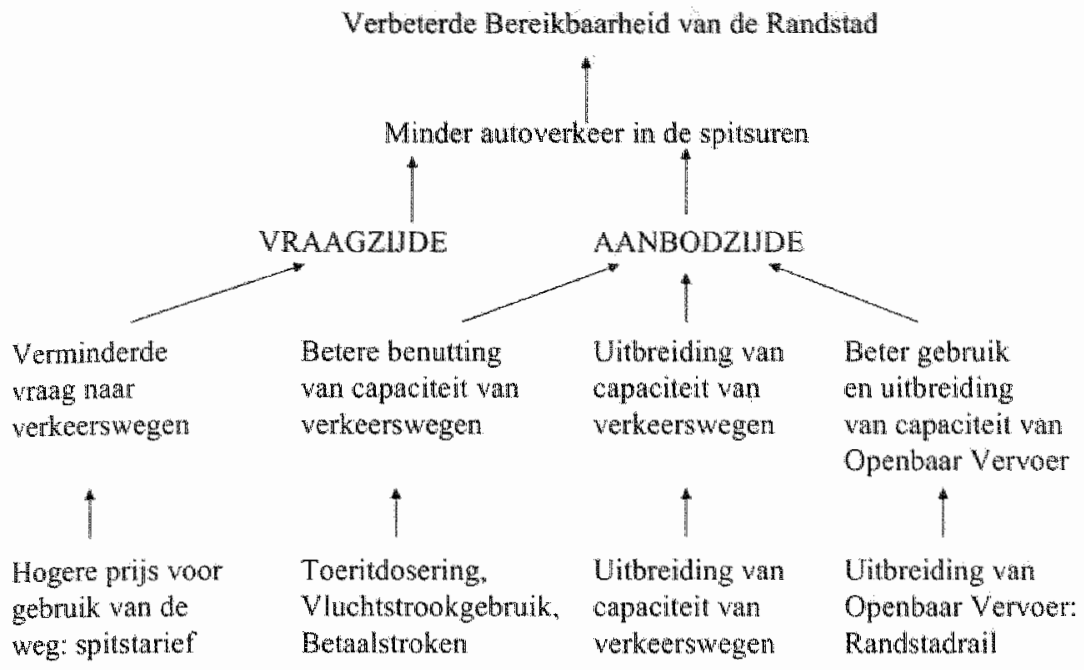

\section{Het elasticiteitsprobleem}

Toetsing van de logica van de probleemboom is de derde stap in de 'log frame analyse'. Ik beperk mij hier kortheidshalve tot de vraag, in hoeverre te veel autoverkeer in de Randstad tijdens de spitsuren kan worden toegerekend aan de te lage prijs voor het gebruik van de weg. Die prijs is thans feitelijk nul. Voor zo ver er een prijs wordt betald in de vom van de Motorrijtuigenbelasting (MRB), is die niet gerelateerd aan het gebruik van de weg en van de auto, alleen aan het bezit van de laatste. Verder worden er door de automobilisten alleen zogeheten 'tijdprijzen' betaald als zij in de file staan.

Prijsverhoging van het gebruik van de weg leidt alleen dan tot substantieel minder gebruik van die weg en tot voldoende substitutie naar andere gebruikstijden of andere vervoersmogelijkheden, als de prijs van de vraag ernaar voldoende elastisch is. Daarmee zijn wij weer aanbeland bij het in paragraaf 2 behandelde elasticiteitsprobleem. En dat is in het vraagstuk van infrastructuurgebruilk een verdraaid lastig probleem. In de Beleidsnotitie zelf wordt als volgt gewag gemaakt van dit probleem (BOR: $\mathrm{p}$ 3): "Bij het vermogen tot substitutie naar openbaar vervoer past een nuancering. Dit is een uiterst complex vraagstuk [zeg dat we II-JvM] en heeft een sterke relatie met de wijze waarop in de Randstad woningbouwlocaties worden gepland. De VINEX-locaties zijn gemiddeld genomen te klein voor het realiseren wan optimaal OV." Terecht wordt gesuggereerd dat de substitutie tussen auto en Openbaar Vervoer vooral afhangt van de beschikbaarheid van de laatste. Op p. 11 wordt geschreven: "Het spitstarief is het verst ontwikkeld, werkt regulerend in de spits, kan snel en eenvoudig worden gerealiseerd $(\ldots . .$.$) en is$ relatief goedkoop." Ja, als je dat maar vaak genoeg zegt, ga je er misschien op den duur zelf in geloven. Maar in de hele Beleidsnotitie wordt nergens een prijselasticiteit van de vraag ook maar genoend, laat staan berekend of geschat. En dat terwijl op p. 13 van de Beleidsnotitie onder thet kopje 'EVALUATIE proeven en pilots' vier indicatoren worden geformuleerd, aan de hand waarvan de korte termijn-effecten (twee jaar na invoering) van het spitstarief zullen worden vastgesteld. Drie ervan worden nota bene gedetermineerd door de prijsela sticiteit van de vraag: 1. verandering van congestie en reistijden op de hoofdwegen tijdens de spitsperiode; 
2. verandering wan verkeersvolume op thet onderliggend wegennet tijens de spitsperiode;

3. verandering van verkeersvolume en de samenstelling naar ritmotieven.

De gewente drie veranderingen worden niet gekwantificeerd, alweer een aanwijzing dat men in de Beleidsnotite met het wasticiteitsprobleem in zijn maag zit.

In de zojuist verschenen "Nota n.a.v. Verslag Rekeningrijden" van hetzelfde Ministerie Guni 2000) wordt in antwoord op diverse Kamerwragen well dieper ingegaan op het elasticiteituproblem. Op p. 41 van de Nota wordt op vragen naar de prijselasticiteit bij de onderscheiden groepen op de weg geantwoord: "In het verleden is veel onderzoek gedaan naar de doorwerking van de exogene variabelen [bedoeld worden de prijsmaatregelen - IvM] in de molviliteitsprognoses in de verschillende beschikbare modellen. Het blikt dan dat bijvoorbeeld de prijselasticiteit in de verschillende modellen in dezelfde orde van grootte ligt. Ook het CPB concludeert in hat publicatie 'Rekening rijden in de Randstad' uit 1998, dat het gehanteerde model op hoofdlijner geschikt is om de belangrijkste aspecten van rekeningrijden in beeld te brengen. De gehanteerde elasticiteiten sporen op hoofdlinen met buitenlandse erwaringsfeiten." Eerder wordi in de Nota (p. 6) daarom ook over de effectiviteit van rekening rijden gesteld: "Desalniettemin geven modelberekeningen in binnen- en buitenland aan dat dergelijke maatregelen tot een substantielle vermindering van de filelast zullen leiden. Deze resultaten worden onderschreven door diverse deskundigen en onlangs ook door het Centraal Planbureau." Modelberekeningen voor het buitenland vinden wil bijwoorbeeld ook in de rapporten van het TRACE project van een Europees consortim, warin ook de Hague Consulting Group deelneent (zie HGC, 1998-1999). Daamaast bevarten handboeken op het terrein van Verkeers- en Vervoerseconomie (bijvoorbeeld Button, 1993 ; De Wit en Van Gent, 1996; Boyer, 1998) schaarse berekeningen van de prijselasticteiten van de wraag naar wegwerkeer.

Wat levert dat allemaal op? Ten eerste laten al die berekeningen verschillende uitkomsten zien, afliankelijk van vooral de ritmotieven (zakelijk versus particulier verkeer), de rittijdstippen (spits- versus daluren) en de eenheid waarin de vraag wordt uitgedrukt (aantal ritten versus aantal kilometers). In Deelrapport 1 van het TRACE-onderzoek van mei 1998 worden op pp. 23-30 de uitkomsten van eerder verricht onderzoek handzaam samengevat. De prijselasticiteit van de vraag naar autobrandstof ten opzichte van het aantal autoritten ligt door de bank genomen (alle ritmotieven, lange termijn) rond $-0,2$. Die elasticiteit is nog kleiner als het gaat om zakelijke ritmotieven. De gemiddelde prijselasticiteit van de vraag naar autobrandstof ten opzichte van het aantal kilometers (opnieuw alle ritmotieven en lange terinijn) is iets hoger, te weten $-0,3$. Die elasticiteit is ook ween kleiner in geval van zakelijke rimotieven. Dat wil zeggen: als de prijs wan autobrandstof toeneemt met tien procent, daalt het aantal autoritten met een vijfde deel daarvan ${ }_{i}$ ofwel met twee procent, en het aantal autokilometers met ongeveer een derde deel daarwan, ofwel met drie procent. Wanneer niet de prijselasticiteit maar de tijdelasticiteit wordt gehanteerd, worden de elasticiteiten slechts marginal groter. De kruiselingse prijselasticiteit van de vragg naar brandstof ten opzichte van het hantal riten respectievelijk het aantal kilometers per openbaar vervoer beloopt ongeveer 0.1. Wanneer niet de kruiselingse prijselasticiteit maar de kruiselingse tijdelasticiteit wordt genomen, loopt de laatste elasticiteit op nat 0,4 . Met andere woorden: als de prijs woor wutobrandstof met tian procent stijgt, neemt het atantal ritten en het aantal kilometers met het openbar vervoer toe met een tiende deel daarvan, ofwel met étu procent. Als de autoritten tien procent langer duren (bijwoorbeeld als gevolg van het fileprobleem), dan stijgen liet aantal ritten en het aantal kilometers met het openbaar vervoer met vier procent. Dit zegt iets over de mate van substitutic tussen beide vervoerswijzen. 
Al met al kan hieruit geen enkele andere conclusie worden getrokken, dan dat de vraig zeer prysinelastisch is. Met een gemiddelde schatting van $-0,25$ kumen wij er zeker niet ver naast zitten. Met andere woorden: de vraagcurve loopt bijna evenwijdig aan de prijsas en de vraag reageert nauwelijks op prijsweranderingen. Als dat klopt, en daar lijkt het tocl wel verdacht veel op, kan het optimisme over de effectiviteit van het BOR dat door het kabinet wordt tentoon gespreid geenszins worden gedeeld. Dan ziet het er veeleer naar wit, dat op voorhand het faillissement van het BOR moet worden aangevragad. Immers, in dat geval gaat het vragg/aanbod-schema van scliema 8 op.

Schema 8. Vraag/aanbod-schema Spitstarief in her BOR

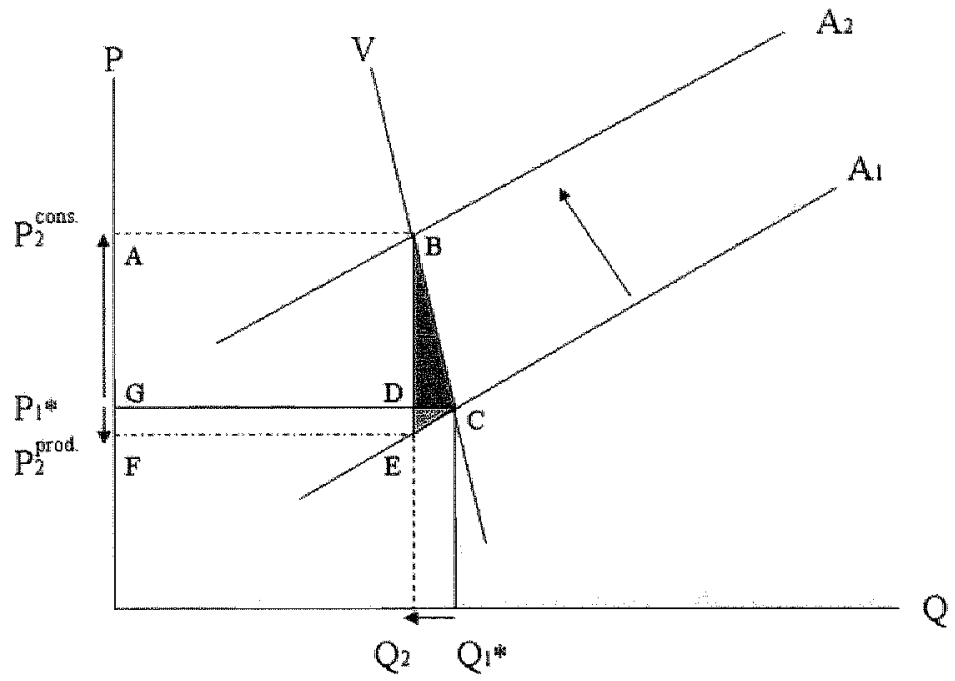

Ik beperk mij hier tot een partiele evenwichtsanalyse, maar de uitkomst van deze vingeroefening is glashelder. In de huidige situatie zonder spitsheffing geld evenwichtspunt $C$, waarin aanbodcurve $A_{1}$ en de wragcurve $V$ alkaar snijden. In dit evenwichtspunt gelden evenwichtshoeveelheid $Q_{1}^{*}$ en evenwichtsprijs $P_{1}^{*}$. Soms worden in zulke vragg/aanbodanalyses de margimale kosten van de consumenten genomen, in plaats van die van de producenten. De aanbodcurve in schema 8 is echter afgeleid uit de marginale kostenlijn van de producenter, de wegbeheerders. Verondersteld wordt dat zij in alk geval op lange termijn de wegcapaciteit en daarmee het aanbod kunnen variëren. Verder veronderstellen wij dat de vraagcurve van de consumenten lineair verloopt (en dus niet discontinu-schoksgewijs). Stel nu dat er congestiekosten woor de automobilist optreden die nog niet in de prijs zijn verrekend. Dat betekent eigenlijk, dat de marginale kostenlijn hoger komt te liggen en dus dat de aanbodcurve naar boven zou moeten verschuiven om deze specifieke exteme effecten te verdisconteren in een zogenoemde "maatschappelijk-economische" (in plaats van bedrijfseconomische) marginale kostencurve. Die verschuiving wordt bewerkstelligd door de invoering van een kilometergebonden spitstarief. De aanbodcurve verschuift daardoor 
omhoog var $A_{1}$ narar A. Het blijk dat inwoering van een spitstantef leidr tot een kleine daling won de netro-producentenpris $P_{1}$ natar $P_{2}$ prot. maar ook tot een excessieve sijg bruto-consumentemprijs van dezelfde $P_{1}$ " haar $P_{2}$ cons. Het verschil $A F$ is de hoogte van het spitstarief he verschil $\mathrm{Q}^{*} \mathrm{Q}_{2}$ is de kleme hoeveelheidsvemindering die dardoor wordt bewerkstelligd. Driehoek BCE is het zogeheten 'dode gewich-welwartsverlies" van de prijserhoging. Dat stuk welvaartsverlies mot in elk geval keiner zijn dan de welvarkwithoging, die resulteert ut de vemindering van de congestiekosten.

De enige die van deze analyse vrolijk wordt is de Minister van Financiën: de opbrengsten bestaan uit vierkant $\mathrm{ABEF}$, maar de Minuster van Verkeer en Waterstaat zal hier minder blij thee zijn. Tel uit je winst De investering wan 10 miljard in het BOR levert zo wel heel erg weing op. Er is een welvartstheoretisch problem opgelost: de schaarste op de weg. is nu geprijscl. Maar die prijsvorming leidt net tot het beoogde resultaat or heeft geen substantiele vermindering van het autoverkeer plazs, want er zal onvoldoende substitutie door het spitstarief worden uitgelokt.

\section{Conchusie}

Uit deze vingeroefening in wh vartsheoretische analyse kunnen de wolgende conchsies worden getrokken. In de eerste plaats leidt de grote prijsinelasticiteit van de viaag naar wegcapaciteit ertoe, dat het voorgestelde systeem wan spitstarieven met tolpoorten in het BOR een aanzienlijk geringere vermindering van de vragg zal bewerkstelligen dan gehoopt. In de tweede plaats zal daardoor, alsmede door het onvoldoende voorhanden zin van adequaat openbaar vervoer in de Randstad (het probleem van de kruiselingse prijselasticiteiten!), de beoogde substitutie van autowerkeer naar openbaar vervoer niet of nauwelijks plaats hebben. Tenslotte zier het er naar uit dat als gevolg van dit alles de automobilisten in de Randstad inderdaad 'betaald in de file" zullen staan, Zij betalen twee keer; én in geldprijzen, de spitstarieven, ến in tijdprijzen. Hun grensnut wan autogebruik, en dus de intensiteit van hun wookkeuren, is zo hoog dat zij daartoe bereid zullen blikken te zijn.

Wat moet er nu gebeuren? Het draait uiteindelijk allemaal om de zo vurig gewenste substitutic die maar niet will lukken. Twee oplossingen liggen voor de hand. De eerste is de invoering van additionele zogeheten 'betallstroken' op de autosnelwegen. Daarmee krijgen de atumobilisten een echte keuze tussen de bestaande gratis rijstroken, waarvoor in tijdprijzen moet worden betaald, en extra rijstroken, warvoor in geldprijzen moet worden betaald. Voor wie tijd geld is, het zakelijke verkeer dus, wordt zodoende substitutie van gratis rijstroken naar de betalstroken antrekkelik. De weede oplossing is versnelde en versterkte invoering van een goed Openbaar Vervoer"systeem in de Randstad, bijvoorbeeld wia Randstadrat. Daannee wordt substitutio van het autoverkeer nar het treinverkear gerealiseerd. Beide oplossingen zullen beter werken dan het in het BOR voorgestelde systeem van spitstarieven, warbij atutomobilisten toitelijk geen keuze hebben.

\subsection{Canmabisgebruik en Gedoogbelend}

Laten wij nu overgaan nat het weede beleidsprogramma, Cannabisgebruik en Gedoogbeleid. Drugs vomer en zichtbaar probleem in de Nederlandse samenteving: stratcriminaliteit. verschillende vomen van overlast en drugstoerisme. Met de regeringsnota "Het Nederlandse drugsbeleid: Continuteit en Verandering" (1997), heeft het tweede kabinet-Kok de hoofdinnen van het drugsbeleid aangegeven. De volksgezondheid staat hierin centraal. Er wordit een onderscheid gemaakt tussen hard drugs met een onaanwaardbaar risico, zoals heröne en cocaine, en minder gevaarljke soft dngs, zoals hash en marihuana. Het drugsbeleid omvat verschillende 
onderdelen. Pas als alle onderdelen van het beleid en de uitvoering goed zijn ontwikkeld en op elkaar afgestemd, wordt de effectiviteit van het drugsbeleid gemaximaliseerd. Het Nederlandse drugsbeleid omvat de volgende onderdelen: preventie, werslavingszorg, bestrijding van internationale drugshandel en drugstoerisme, extra aandacht voor XTC en vijf andere synthetische dnigs, wetgeving, en vermindering van de drugsowerlast.

Het Nederlandse drugsbeleid is in de Westerse wereld onstreden. In een zojuist verschenen overzichtsartikel maakt de Amsterdamse socioloog Van Ree (2000) de balans op van honderd jaar drugsbestrijding. Naar zijn mening is het middel erger dan de kwaal. In de Verenigde Staten heeft deze bestrijding onder meer geleid tot een aantal totalitair aandoende neveneffecten: buitensporige strafmaat, verbeurdverklaring van goederen en "conspiracy"wetgeving. Hij vraagt zich af of het in Nederland ook zo'n vaart zal lopen. De Amerikianse drankdrooglegging ('Prohibition") in de jaren dertig heeft aangetoond, dat excessieve repressie van (vermeend) verslavingsgedrag averechts werkt. De vraag kan immers niet worden uitgeroeid, waardoor er illegaal aanbod ontstaat. Daarin ligt de verklaring voor de opmars van de Maffia (Al Capone; zie ook de bekende tv-serie "The Untouchables" uit de jaren zesiig). Kunstmatige schaarste maakt georganiseerde misdaad aantrekkelijk, ondat het aanbod tegen hoge prijzen kan worden geleverd maar met een slechte kwaliteit. Daardoor snijdt het mes aan twee kanten: hogere prijzen en lagere kosten, en dus superwinsten. Door de hoge prijs gaan mensen bovendien ook zelf illegaal stoken, met nog grotere kwaliteitsproblemen tot gevolg. Na enkele jaren werd daarom in de Verenigde Staten de Drooglegging weer opgeheven. De maatschappelijke kosten van de Drooglegging bleken uiteindelijk vele malen groter dan de tegenvallende maatschappelijke baten. Met Van Ree kan men zich afvragen, of dit eigenlijk ook niet geldt voor de drugsbestrijding.

In vergelijking met andere West-Europese landen heerst in Nederland een liberale traditie in het drugsbeleid. Gepoogd wordt een evenwicht te bewaren tussen het zogenoemde 'medischmaatschappelijke model', waarin preventie en verslavingszorg centraal staan, en het 'strafrechtelijke' model, waarin bestraffing en bestrijding worden benadrukt. Een fraai voorbeeld wan de typisch Nederlandse drugsbenadering is het zogeheten "Gedoogbeleid" ten aanzien van cannabisgebruik. Cannabis is in Nederland de meest gebruikte illegale drug. Elke handeling met dir middel is verboden, behalve het persoonlijk gebruik. De handhaving van een aantal onderdelen van dit wettelijk verbod heeft echter geen hoge prioriteit, overtreding wordt onder bepaalde voorwaarden gedoogd. Een en ander staat letterlijk te lezen in de zeer recente Beleidsnotitie 'Het Pad naar de Achterdeur' (apri1 2000) van het Ministerie van Justitie. Dat leidt tor de opmerkelujke paradox, dat cannabis wel via de voordeur van de bekende coffecshops mag. worden verkocht, maar niet via de achterdeur door leveranciers mag worden geleverd. Hypocrieter kan het niet. In elk geval kan dat in het buitenland niet worden uitgelegd. Van Reo constateert echter ook een sluipend prohibitionisme in Nederland. Recreatief drugsgebruik word steeds minder aanvaard, uitsluiting van drugsgebruikers echter steeds meer. Daardoor wordt volgens hem een open debat ower dit sluipend prohibitionisme urgent.

Beperking van het gebruik van soft drugs kan met twee argumenten uit de welvaartstheorie worden verdedigd. Het eerste argument is dat van de externe effecten. Het gebruik van soft drugs veroorzaakt kosten (van overlast en ongemak) voor anderen butten de markt om, die zelf geen drugsgebruikers zijn. Zij dienen te worden beschermd. Het tweede argument is dat vain 'demerit'-averwegingen, ofwel het 'patemalistische motief. De gebruiker van soft drugs moet tegen zichzelf worden beschermd. Het eerste argument zal eerder door liberalen worden gebruikt, het tweede eerder door socialisten. Het is zaak beide argumenten goed uit elkatr te houden. In geval van externe effecten worden de individuele woorkeuren van consumenten en producenten geëerbiedigd. Alleen worden door overheidsinterventie de prijsverhoudingen 
aangepast aan de echte schaarsteverhoudingen. Producenten- en consumentensuplus vormen samen de collectieve welwartsmatstaf. In geval van paternalistische motieven voor overheidsinterventie worden de individuele voorkeuren doorknisit. De beleidsmakers menen dan beter te weten wat goed is voor de individuele gebruikers, dan die gebruikers zelf. Het consumentensurplus vomit derhalve geen onderdeel meer van de welvaartsmaatstaf, omdat de omstandigheid dat gebnukers plezier beleven (in economentaal: positief nut ontlenen) aan soft drugs, door de beleidsmakers niet wordt aanvaard. Dit onderscheid maakt wel degelijk verschil voor de welvaartstheoretische analyse, zoals wij hieronder nog zullen zien.

\section{Van probleemboom naar doelstellingenboom}

Laten wij het Nederlandse drugsbeleid nu eens aan een LFA onderwerpen, met daarin speciale alandacht woot cannabisgebruik en gedoogbeleid. Opnieuw moet ik mij in het bestek van deze oratie beperken tot een vingeroefening. Hoogerwerf (1998; pp. 20-31) presenteert een aardige causale analyse van het drugsgebruik in Nederland in zijn inleidend hoofdstuk over "het ontwerpen van beleid als wetenschapstoepassing". Die analyse is in de volgende probleemboom te vertalen (schema 9).

\section{Schena 9. Probleemboom in het Nederkindse drugsbeleid}

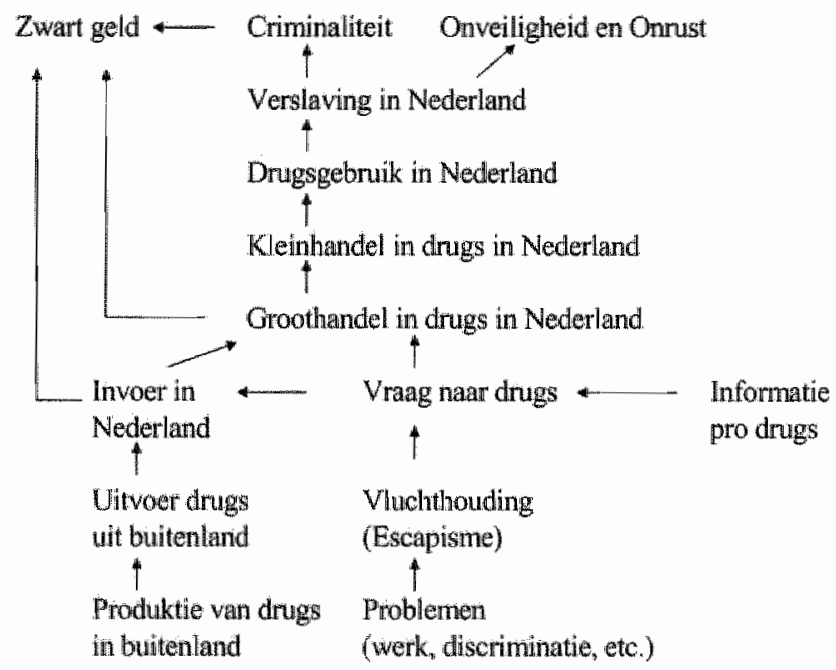

Daarbij hoort de volgende toelichting. Hoofdproblemen zijn het zwart geld, de criminalliteit en de onveiligheid en onnust die worden veroorzakt door verslaving. Verslaving hangt samen met drugsgebruik in Nederlind. De vraag naar drugs lokt, naast bimenlandse produktie, invoer ervan uit her buitenland uit. In dit causale model wordt de wraag naar drugs veroorzaakt doot zogeheten "escapisme" (vluchthouding) als gevolg van persoonlijke problemen.

De vertaalslag naar de beleidstheorie levert de volgende doelstellingenboom van het Nederlandse drugsbeleid op (schema 10). 


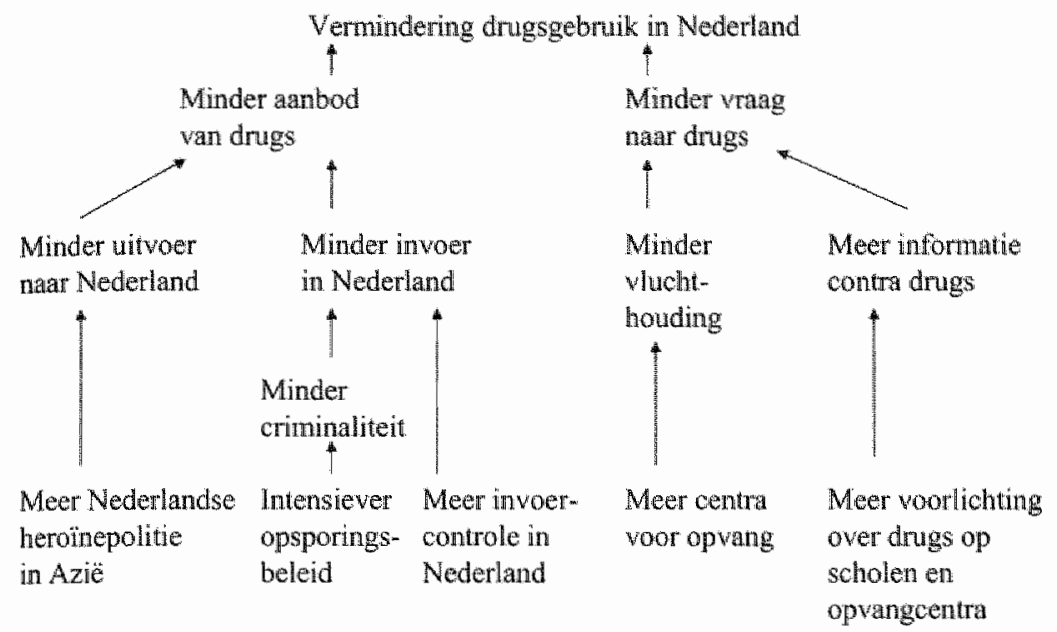

\section{Het elasticiteitsprobleem}

Toetsing van de logica van de probleemboom is de derde stap in de 'log frame analyse'. Een uitgebreide economische analyse van drugsbestrijding wordt gepresenteerd door Miron en Zwiebel (1995). Die analyse is ook relevant voor het Nederlandse gedoogbeleid inzake soft drugs. Ik moet mij hier echter kortheidshalve beperken tot de vraag, in hoeverre het drugsgebruik in Nederland kan worden toegerekend aan het tolerante drugsbeleid met betrekking tot soft drugs, zoals dat tot uiting komt in het boven gememoreerde gedoogbeleid. In elk geval kan worden vastgesteld dat het restrictieve onderdeel van dit beleid, het verbod op alle handel, leidt tot prijsopdrijving, omdat daarmee het aanbod illegaal is gemaakt. Daardoor wordt het aanbod werminderd en dus de schaarste vergroot, met als resultaat een hogere prijs bij een gegeven vraag. Dat komt voor de producent goed uit, ondat het aanbieden van soft drugs cen riskante want illegale bezigheid is. De aanbieder wenst daarom een risicopremie in zijn prijs te verrekenen. Die risicopremie wordt automatisch geincasseerd via de prijsverhoging. Met andere woorden: er wordt op deze wijze kunstmatige schaarste veroorzaakt, waardoor de aanbodcurve naar boven zal verschuiven. Een en ander kan worden geanalyseerd met een partiële (en dus beperkte) evenwichtsanallyse van de markt voor cannabis. In schema 11 wordt een vraag/aanbod schema van de cannabismarkt onder gedoogbeleid in Nederland gejresenteerd. 


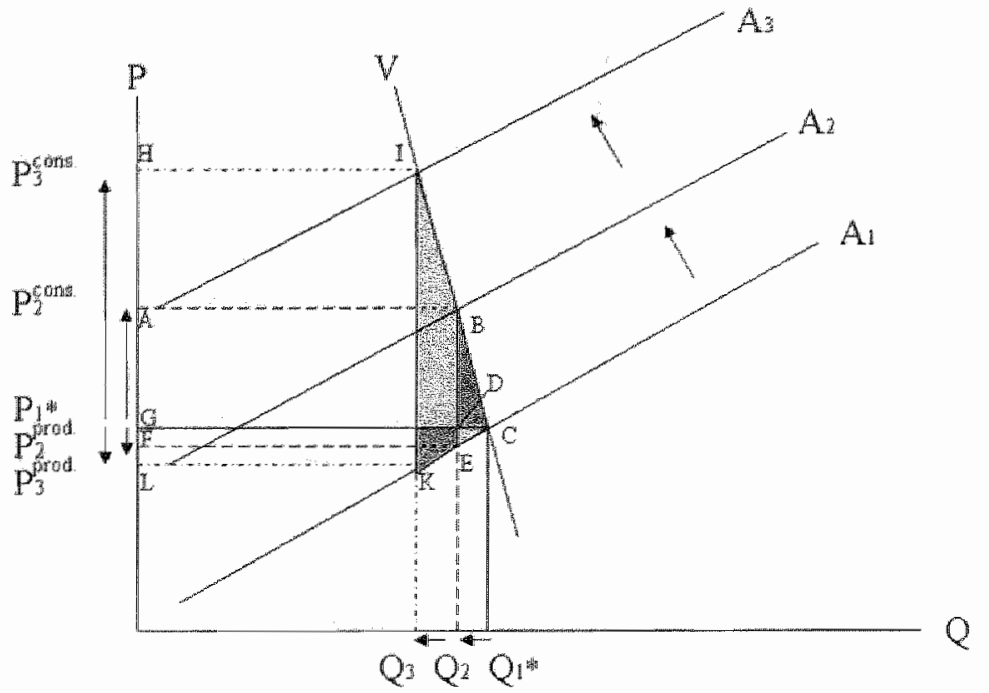

Bij een volstrekt geliberaliseerd beleid, waarin produktie, distributie en gebruik van cannabis wolledig wrij zijn, resulteert aanbodcurve $A_{1}$. In combinatie net de vraagcurve $\mathrm{y}$ ontstaat een evenwichtspunt $\mathbb{C}$ met evenwichtsprijs $\mathbb{P}_{1}$, en evenwichtshoeveelheid $Q_{1}{ }^{*}$. Er wordt volledige mededinging verondersteld. In deze situatie worden consumenterv- en producentensurplus, en daarmee de collectieve welvaart, gemaximaliseerd.

Onder het regime van het gedoogbeleid wondt de handel in cannabis verboden, maar in de praktijk selectief aangepakt, terwijl het gebruik ongemoeid wordt gelaten. Daardoor is sprake van enige restrictie in het aanbod. De aanbodcurve verschuift omhoog naar $A_{2}$. Er is echter sprake van een grote prijsinelasriciteit van de vraag. Dat geldt over het algemeen voor vers avende goederen: de vratg is relattef prijsongevolig. Er word een nieuw evenwichspunt $B$ bereikt, Daarin loopt de afgezette hoeveetheid terug wan $\mathrm{Q}_{1}$ naar $\mathrm{Q}_{2}$, de bruto-consumentenprijs loopt flink op wan $\mathrm{P}_{1}$ " naar $\mathrm{P}_{2}{ }^{\text {cons. }}$. De netto producentenprijs daalt licht van $\mathrm{P}_{1}{ }^{*}$ naar $\mathrm{P}_{2}$ prod. De producenten incasseren echter een extra producentensurplus ter grootte van rechthoek $\mathrm{ABEF}$, dat algeroomd word van het consumentensurplus. Er heeft als het ware herverdeling plaats van consumenten natar producenten. Als gevolg van zijn prijsinelastische vaag betalt de consument het gelag van het gedoogbeleid. De 'economische rent' van dat beleid wordt geind door de producent. Ondat daruit echter de extra risico's worden gedekt on dit dus geen zuvere welvaztstoename voor de producent betekent, kan dit misschien beter een "quasi-rent" worden genoemd. De producent heeft er dus ook alle belang bij dat er een restrictief cannabisbeleid wordt gevoerd. Dat wordt ook bevestigd in het Maastrichtse Wetenschapswinkelonderzoek van student Florian Satzinger (2000), dat ik mocht begeleiden. Daarmee komen wij uit op 'rent seeking" als verklaring voor het producentengedrag (zie hiervoor Tullock, 1993). Bovendien is de extra hoevelheid surplus die wordt afgeroond, klemer dan het totale verlies aan 
consumentensurplus: Het verschil is het bekende "dode gewicht-welvaartsverlies" van drichoek $\mathrm{BCE}$.

Wanneer een volledig prohibitionistisch beleid wordt gevoend, wordt alle produktie, distributie en consumptie van cannabis werboden. De aanbodeurve verschuif nog vender omhoog naar $\mathbb{A}_{3}$. Het wordt immers nog riskanter om soft drugs aan te bieden. Er ontstat een nieuw evenwichtspunt I. Daarin is de afgezette hoeveelheid verder teruggelopen van $\mathrm{Q}_{2}$ naar $\mathrm{Q}_{3}$. De

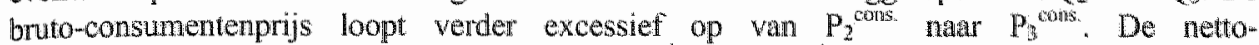
producentenprijs loopt verder licht tenug van $\mathrm{P}_{2}{ }^{\text {prod. }}$ natr $\mathrm{P}_{3}{ }^{\text {prod. }}$. De producenten incasseren een nog groter producentensurplus ter grootte van rechhoek HIKL, dat wederom afgetoond wordi van de conswmenten. Er heeft verdere herverdeling plats wan consumenten nar producenten. De prijsinelasticiteit van de vraag geeft de producenten de gelegenheid om de consumenten nog verder uit te persen. 'Rent seeking' loont in deze prohibitionistische stuatie $\left(\mathrm{A}_{3}\right.$ !) voor de producenten nog meer de moeite (al wordt de noodzakeljike risicopremie daarmee navenat groter), dan onder een gedoogbeleid $\left(A_{2} !\right)$. Het 'dode gewicht-welvaartsverlies' wordt ook groter en wordt gevormd door driehoek ICK.

Hierbij moet worden aangetekend, dat deze welwantstheoretische analyse alleen geldig is, wanneer het externe effecten-argument wordt gebrikt om soft drugsi-gebruik te bestrijden. In dat geval mag namelijk de gezamenlijke onvang van het consumenten- en producentensurplus worden gebruikt als collectieve welwaartsmatstaf. Als evenwel patemalistische motieven worden gehanteerd, wordt de legitimiteit wan het bestaan van een consumentensurplus uit soft drugs-gebruik betwist. Daardoor valt dit onderdeel weg uit de collectieve welvaartsmatstaf en zou de analyse van de collectieve welvartseffecten wel eens anders kunnen uitvallen.

\section{Conclusie}

Welke lessen kumen nu uit deze vingeroefening worden getrokken? lk trek de volgende conclusies, waarbij moet worden aangetekend dat deze zijn gebaseerd op een strikt welvaartstheoretische en partiele analyse onder de veronderstelling van het externe effectenargument voor overheidsingrijpen in soft drugs-gebruik. Andere overwegingen blijven hier dus buiten beschouwing, maar de sombere gevolgtrekkingen van de boven aangehaalde socioloog Van Ree worden er wel door bevestigd.

1. Prijsinelasticiteit van de vraag leidt ertoe dat niet alleen prijsmaatregelen, maar zelfs fysieke regulering niet het beoogde effect van minder cannabisgebruik sorteert.

2. Vanuit welvartstheoretisch gezichtspunt is volledige liberalisering van liet cannabisgebruik het beste alternatief, gedoogbeleid het nasstbeste altematiof volledig prohibitionisme het slechtste alternatief.

3. Als gedoogbeleid wordt ingeperkt in de richting van prohibitionisme, zijn wij met zijn allen vanuit het geaichtspunt van de collectieve welwaart slechter af. Het 'dode gewichtswelvaartsverlies" wordt dan immers anzienlijk.

4. Camnabisaanbieders hebben er belang bij dat het gedoogbeleid wordt aangescherpt in de richting van prohibitie. Ondat de vraag prijsinelastisch is, kunnen zij immerg hun prijzen flink verhogen en zodoende een substantieel gedeelte van het consumentensurplus aftomen. Dil noemen wij in de public choice-benadering "rent seeking"-gedrag.

5. Wanneer levering van camabis aan de achterdeur van coffeeshops wordt toegestaan, wordt een adequat tegenwicht geboden tegen de tendens om het gedoogbelleid in de richting van prohibitionisme bij te buigen (zie de Beleidsnotitie "Het Pad naar de Achterdeur", april 2000, van het Ministerie van Justitie). 
Deze conclusies komen overigens overeen met die welke Miron en Zwiebel trekken in hun bovenvermelde economische analyge van drugsbestrijding uit 1995 , die zij met opzer hebben voorzten van de tel "The economic case agatinst drug prohibition".

Ter afsuiting blikt uit deze welvaartstheoretische analyse, dat de burgemeesters van middelgrote steden als Tilburg, Nijmegen, Venlo en Heerlen (waar het gedoogbeleid niet meer in de pas loopt net het cannabisprobleem) groot gelijk hebben, warneer zij ijveren voor legalisering wan de lewering van cannabis aan de achterdeur van coffeeshops. Ook kan het aantal cofteeshops beter niet worden teruggedrongen, (wat volgens de ciffers wel de heersende trend blijk te zijn), ondat door dit verkoopkanall het cannabisgebruik beleidsmatig veel beter kan worden beheerst en de misstanden wan overlast en stratcriminaliteit kumen worden teruggedrongen. De belangrikste les is opnieuw, dat grote prijsinelasticiteit van de vraag terugdringing van die vraag nagenoeg onmogelijk maakt. Die les zouden wij toch een keer moeten leren. In elk geval heeft een meerderheid van de Tweede Kaner die les inmiddels wél geleerd (de Volkskrant, 28 juni 2000). Nu moet de bewindsman nog door de bocht.

\section{BELEIDSFALEN: WAT IS ER MIS?}

De twee beleidsprogramma's die hierboven an een eerste analyse zijn onderworpen, staan niet op zichzelf. Zij zijn exemplarisch woor beleidsfalen van beleidsprogramma's in het algemeen. De laatste jaren wordt zulk beleidsfalen steeds vaker aan de kaak gesteld in kritische rapporten van bijvoorbeeld de Algemene Rekenkaner (die zijn horzelfunctie steeds beter vervult!) en breed uitgemeten in pers en publieke opinie. Ik geef enkele voorbeelden in willekeurige volgorde per beleidssector.

In de ruimtelike infrastncturo gat het om projecten als de uitbreiding van Vliegveld Schiphol; de aanleg wan de Oost-West-baan van Vliegveld Beek; de Hoge Snelheidslijn en de Betuwelijn (zie het rapport 'Beleidsinformatie Betuweroute", van de Algemene Rekenkamer van vorige week, 22 juni 2000 !); de uitbreiding en modemisering van een integraal wegennet; de nierwe problemen van de VINEX-locaties; nieuwe problemen van verstedelijking en stadsvernieuwing; de drie Maaswerken (Grensmaas, Zandmaas en MOMARO); diverse natuurontwikkelingsprojecten; planning en modemisering van industrieterreinen en bedrijventerreinen.

In de gezondheidszorg de budgetteringsproblematiek; de aanpak van het wachtlijstprobleen; de beheersing van de medicijprijzen; de planning van de opleiding van tandartsen, huisartsen en specialisten; de arbeidswoorwaarden en beloningsstructuur van verplegend personeel en specialisten; de herziening van het zielktekostenverzekeringstelsel; de herinrichting van de thuiszorg, verpleeginrichtingen en verzorgingshuizen (net inbegrip van onderlinge afstenming): de invoering van marktwerking, ook onder druk van Europese regelgeving an mededingingspolitick; de aansturing van schaalvergrotingsprocessen en technologische ontwikkelingen.

In het andemijs de reorganisatie van het voortgezet onderwijs, met name de invoering van het studieprofiel en her studielhus met het oog op de aansluiting tussen voortgezet onderwijs en hoger beroepsonderwijs/wetenschappelijk onderwijs; het probleem van toezichthouding (inspectie) in relatie met kwaliteitszorg en tweedeling in witte en zwarte scholen; de planning van de opleiding van docenten; arbeidsvoorwaarden en beloningssystematiek van onderwijzend personeel; professionalisering van het management van onderwijsinstellingen; aansturing van processen van schalvergroting; de invoering var de Bachelor/Master-structuur in het: wetenschappelijk onderwijs (Bologna-verklaring). 
In de sociale zekerheid marktwerking en privatisering wan onderdelen wan het socials verzekeringsstelsel; het probleem van de amoedeval in relatic met basisinkomen on negatheve inkomstenbelasting; de relate tussen sociale zeketheid en toetredingsbelemmeringen tor de arbeidsmarkt; het probleem van instroom/uitsmoom van zektewet en WAO; het reintegratie. vraagstuk; de Centra voor Werk en Inkomen; de medische keuringsproblematiek.

Dat is een lange lijst; ik kan maar beter stoppen met deze opsomming: De woorlopige witkomsten van de beleidsanalyse van twee beleidsprogramma's in de vorige paragraa, worden bevestigd door allerlei problemen in deze bonte rij van beleidsprogrammats. Wat gaat daarin nu echt mis, op grond waarvan de conclusie moet worden getrokken dat sprake is van beleidstalen? Ik noem de volgende vier oorzaken van beleudshalen:

1. Iacunes in de wetenschappelijke onderbouwing van beleid, ofwel kenuislacunes;

2. valkuilen in de vertaalslag naar de beleidstheorie;

3. cognitieve dissonantie en blinde ideologische vooringenomenheid:

4. inadequate sturingsfilosofie.

De eerste twee categorieèn zijn in de kern van de zak methodologische problemen, die hierboven al uitvoerig aan de orde zijn gesteld (zie paragraf 2). Daarom kan de behandeling daarvan nu kort zijn. De laatste twee categorieën hebben te maken met de manier, waarop onze samenleving wordt bestuurd. Dat is belangrijk genoeg on er wat dieper op in te gaan.

\section{Kennislacunes}

De wetenschappelijke onderbouwing van beleid laat meer te wensen over dan ons lief is, en ook veel meer dan veel beleidsmakers en beleidsadviseurs en sonmige onderzoekers willen doen voorkomen. Alle bovengenoemde categorieën van intern-methodologische problemen komen in de praktijk voor. Hoe valk worden alle causale verbanden in de probleemboom (stap II in de 'log frame analyse') nu echt gekwantificeerd? In de twee geanalyseerde beleidsprogramma's bleek het uiteindelijk aan te komen op het elasticiteitsvraagstuk. Hoe groot nu eigerilik de prijselasticiteit van de vraag is; blijkt cruciaal voor het succes of falen van die beleidsprogramma's, maar infonmatie over dergelijke vitale parameters is nauwelijks aanwezig. Hard mpirisch onderzoek ontbreekt te vaak evenals schattingen, terwijl er voldoende undicaties zijn on prijsinellasticiteit te veronderstellen. In dat geval is falen van het betrokken beleidsprogramma gegarandeerd. Met name het Cannabis-gedoogbeleid in Nederland is hierop feitelijk stuk gelopen, terwijl het Bereikbaarheidsoffensief Randstad dat hierop vrijwel zeker zal doen.

\section{Valkwilen in de vertadslag}

Maar het wordt nog erger. Stap 2 van de "log frame analyse" bestat uit toetsing van de doelstellingenboom in de gereconstrueerde beleidstheorie. Hoe vaak worden de finaalinstrumentele relaties in de beleidstheorie nu ech getoetst op hun intern-logische consistentie en op hun empurische houdbaarheid? Bovendien hebben wij gezien dat de kwaliteit van de beleidstheorie wordt bepaald door de kwalftent vat de onderliggende wetenschappetijk causale theorie. Als die grondslag niet in orde $\mathrm{is}$, kan het niet meer goed komen met de beleidstheorie en moet het met het daarop gebaseerde beleidsprogramma onherroepelijk slecht aflopen.

\section{Cagnitieve dissonantie en blinde ideologische pooringenomenheid}

Een volgende verklaring ligt in de omstandigheid dat mensen, en dus ook beleidsmakers, de neiging hebben om infomatie over de empirische werkelijkheid, die niet strookt met hun opvattingen of voorkeuren, te negeren of an te passen. Het al gememoreerde Algemene Rekenkamer-rapport over de kwaliteit van de politieke investeringsbeslissing over de Betuwelin 
laat onbarmhartig zien, dat andersoortige informatie over kosten en baten van die investering wel degelijk woorhanden was. Maar deze informatie werd stelselmatig genegeerd, van tafel geveegd en niet serieus genomen, ondat zij niet strookte met de informatie die gebruikt kon worden om tot een positieve beslissing te komen. Dit verschijnsel staat bekend als "cognitieve dissonantie". Ook beleidsmakers is niets menselijks yreemd.

Een andere variant is blinde ideologische vooringenomenheid. Bij cognitieve dissonantie is nog sprake van goede trouw, bij blinde ideologische vooringenomenheid wordt de grens naar kwade trouw overgestoken. In dat laatste geval worden feitelijke informatie en sconomischrationele afwegingen van kosten en baten van alternatieven ondergeschikt gemaakt aan ideologische voorkeuren. 'Als de feiten miet kloppen met de theorie, des te erger voor de feiten'. De voortdurende aanpassing van de veiligheids- en milieunomen rond Schiphol, on de gewenste uitbreiding maar mogelijk te kunnen maken, is hiervan een voorbeeld. De aanleg van de Betuwelijn is een ander voorbeeld: als eenmaal een strategische keuze is gemaakt doet, onder verwijzing natar het belang voor Rotterdam en 'Nederland Distributieland', nieuwe informatie over desastreus-tegenvallende toekomstige vraag naar goederenvervoer per spoor (als gevolg van substitutie naar de LJzeren Rijn, de binnenvaart en het wegverkeer) en verdampende milieuwinst er niet meer toe. Dan bestaat de verantwoordelijk minister van Verkeer en Waterstaat Netelenbos. het zelfs om te roepen, dat "de werkelijkheid niet in prognoses kan worden gevangen". Je moet maar durven!

\section{Inadequate sturingsflosofie}

Dan kom ik uit op misschien wel het grootste kwaad: een inadequate sturingsfilosofie. De 'maakbaarheidsideologie' van de jaren zeventig heeft diepe sporen getrokken in onze manier van beleidsvorming en van besturing van de samenleving. Ondanks alle inspraak en andere formele beïnvloedingsmogelijkheden in het voortraject, lijken beleidsmakers zich nog steeds te gedragen als politieke ingenieurs, die kant en klare keukentafeloplossingen bedenken voor beleidsproblemen en daarbij zijn gevangen in 'blauwdrukdenken' en 'viltstiftplanning'. Synoptisch-rationele planningsmethodologie is nog steeds populair. Gesloten beieidsprogramma's worden ontwikkeld onder de stilzwijgende veronderstelling, dat alle benodigde informatie en kennis voorhanden is of kan worden gegenereerd, en kan worden verzameld en verwerkt in één Centrale Planningsinstantie: het Centraal Planbureau, beleidsafdelingen wan de ministeries, beleidsondersteunende instanties, advies- en begeleidingscommissies, enzovoorts.

Dit heb ik al vaker 'Stalinistisch Planningsdenken' genoemd. Het gigantische, megalomane staatsplanbureau GOSPLAN in de hoogtijdagen van het Soviet-plancommunisme is er niets bij. Dat leidt vervolgens tot 'Sovietisering' van het beleidsproces en van onze politiekbestuurlijke orde. Dat bracht al wat langer geleden onze Amsterdamse collega Bart Tromp (in het tijdschrift 'Socialisme en Democratie' (sic!), 1992) ertoe, on te spreken van 'sovietisering van de universiteit' en recent gebruikte Paul Frissen in de Volkskrant (van 20 mei 2000) dezelfde kwalificatie in zijn tirade tegen de 'sovietisering van de gezondheidszorg' in Nederland. Het is ook well wrang: in Oost-Europa wordt de communistische planeconomie afgeschaft, ondat die de economische orde aldaar zo ongeveer te gronde heeft gericht, in West-Europa voeren wij hem in, gettige het vastklampen aan fysieke rantsoeneringsmechanismen in de ruimtelijke infrastructuur, de gezondheidszorg en het onderwijs, die allang hebben bewezen niet te werken en het allemaal alleen maar erger lijken to maken.

Juist economen zouden beter moeten weten. Zijn wij de lessen wan het 'Socialistische Calculatiedebat' (zie Hayek, 1956) dat in de jaren twintig en dertig werd gevoerd, dan vergeten? Zijn wij de Hayekiaanse verdediging van de superioriteit van het prijsmechanisme in de jaren veertig dan uit onze herinnering verloren, om over zijn 'Road to Serfóm' (1944) niet eens te 
spreken? Zijn wij de lessen van de algemene evenwichtstheorie, wwee weken geleden op deze zelfde plek nog eens zo praclatig uitgelegd door collega Herings in zijn oratie (Herings, 2000), dan kwijt geraakt? Het wordt tijd woor "echte economen" on zich te bemoeien met de discussie over betere sturingsmechanismen ten aanzien wan onze gemengde economische orde en over een andere, meer adequate sturingsfilosofie in de publieke sector. Die discussie moet miet aan alleen aan bestuurskundigen worden overgelaten. 'Echte economie' hesft hier zeker voegevoegde watde.

\section{BELEIDSOPLOSSINGEN: WAT KAN ER AAN WORDEN GEDAAN?}

Hoe lossen wij al die problemen nu op, wat kan er aan worden gedaan? Uitgangspunt zou moeten zijn dai er minder owerheidsbeled moet zijw maar wel beter, in analogie met een kleinere overbeid, maar wel een betere. Is het mu echt nodig dat elk probleem tot een maatschappelijk probleem wordt verklaard, warvoor de overheid een oplossing moet bieden met behulp wan overheidsbeleid? Ondanks slogans als "overheid op arstand" en wat dies meer zij, is er nog steeds de instinctieve reactie on terug te grippen op overheidsinterventie als er een maatschappelijk probleem wordt gesignaleerd. Oude gewoonten zijn ingesleten en lijken onuitroeibaar. Ik herinner mij uit mijn Universiteitstaad-periode hier in Maastricht dat een studentraadslid uitriep, toen het College van Bestuur meldde dat er op een bepaald onderdeel geen universitair beleid was ontwikkeld. "Nou, dan moet dat er maar gauw komen!" "warop mijn reactie was: "Hoezo? Waarom? Is er een probleem dan?" Dat werd mij nict in dank afgenomen. Dit voorval deed zich voor tond 1990, nog maar tien jaar geleden. Intussen is er nog marar weinig ten goede veranderd. Onze Tilburgse collega Witteveen pleitte daarom een tijdje geleden voor een algemeen "beleidsmoratorium": mak eens een tijdje geen beleid en zie wat er gebeurt. Dat gaat misschien wat ver, maar er zijn ook andere aangrijpingspunten.

\section{Horizontaal-denocratische besmingsfilosofie}

Om te beginnen zou eindelijk eens een einde gemaakt moeten worden aan de verticaalhiërarchisch besturingsfilosofie die veel beleidsprogramma"s kenmerkt. Dat past toch niet meer in de huidige tijd. Daamee is jeder verstandig mens het eens, maar toch overheerst nog steeds deze manier van denken in overheidsbeleid. De moderne samenleving wordt steeds meer langs horizontale lijnen georganiseerd, oude machtsconcentraties worden verpulverd en nieuwe machisconcentraties zijn volatiel en dus geen lang leven beschoren. De samenleving bestaat wooral uit dynamische netwerkorganisaties en netwerken van zulke organisaties. 20 ontstaan er ook horizontale beleidsnetwerken, warin mach word gefagmenteet en de overheid geen exclusief machtsmonopolie meer heef. Daarbij past een meer horizontad-democratische besturingsfilosofie, warin de overheid shechts én van de vele deelnemers in het beleidsspel is, marar wel een bijzondere.

De rol van de overheid is daarin wezenlijk anders. De rol van de overheid word in dat geval die van "procesarchilect' die verantwoordelijk is voor de procesarchitecturr van het belleidsproces (zie In 't Veld, 1997; 1999). In overleg met de deelnemers worden de regels van het spel gemaakt. De overheid bewaakt de naleving wan die regels en corrigeert zonodig. De uitkomst van het spel is dan optimal, ondat de spelregels optimaal zijn gemaakt en ondat naleving ervan wordt bewaakt en zo nodig afgedwongen. Hier dringt zich de analogie met marktwerking en mededingingspolitiek op, met specifieke aandacht voor de cruciale rol daarin van de Nederlandse Mededingingsautoritet (NMa). In deze rol dreigt er nog steeds het gevaar 
wan de overheid als "meespelende scheidstechter" maar ook daarvoor 2 inn oplossingen te bedenken.

\section{Meer besched denheid}

In de tweede plaats zow het besef dat menselijke kennis en inzicht per definitie beperki zijn en blijven ("la condition humaine", of 20 u witt de "Erfonde") en dat ook niet alles in beleidswerkelijkheid vertalbaar ${ }^{\prime s}$, crtoe moeten leiden dat beleidsmakers, en in hun kielzog die hele horte van beleidsadviseurs, organistitie-adviseurs, toegepaste beleidsonderzoekers en "consultants", bescheidener worden ower hun eigen mogelwheden die werkelikheid naw hw hand te zettew. Wij kunnen immers niet weten wat wij niet weten. Niemand heef daarom de wijsheid in pacht, ook beleidsmakers niet. Minder pretenties, maar daarom naturulik niet minder ambities. De arrogantie van de macht en van het eigen gelijk schuilt overal. De uitspraak. "we run thing country word toegeschreven aan het CDA (meer in het bijzonder het Tweede Kamer-lid Joost van Jersel), maar de besturingsfilosofie van Paars ademt dezelfide amogantie. Een pleidooi dus voor een oefening in bescheidenheid, en dat miet alleen voor economen (zie de prachtige afscheidsrede van Wotson, 1998), maar ook voor beleidsmakers.

\section{Versterking wan terugkoppelingsmechanismen}

Voorts kan zo'n meer bescheiden opstelling een handje worden geholpen door mechanismen in het beleidsproces in te bouwen, die verkeerde beleidsbeslissingen signaleren en zo nodig corrigeren. Alleen informatieverzameling en -werstrekking is niet genoeg, zo leet ons het wedervaren van de Algemene Rekenkamer-rapportages. Alle relevante beleidsinformatie dient niet alleen ter beschikking te worden gesteld, maar er moet ook iets mee gebeuren in het beleidsproces. Dat betekent dat in het beleidsproces meer en betere terugkoppelingsmechanismen moeten worden aangebracht. In dit opzicht is Hirschman's klassieker 'Exit, Voice and Loyalty" (1970) nog steeds actueel. Exit-opties (beter bekend als "stemmen met de woeten") hebben zich bewezen op de markt, waarom zonden die niet creatief kunnen worden beproetd in de publieke sector? Daarvoor is wel echte concurrentie aan de aambodzijde nodig. Alleen dan valt er immers voor beleidsconsumenten iets te kiezen.

\section{Organisatie van marktoplossingen}

Daamee komen wij unt op de organisatie van marktoplossingen in de publieke sector. Hier ligt een mooie taak voor de overheid als procesarchitect. Dan gaat het om de constructie van "quasimarkten" (zie LeGrand en Bartlet, 1993) en van "quasi-prijsmechanismen" (zie Walsh, 1995). Men hoeft geen gelovige te worden in de fundamentalistische leer van New Public Management (NPM; zie Aucoin, 1990, en Hood 1991), on van de analyse en de aarbevolen oplossingen van deze benadering te leren. Tussen de tucht van de "echte" markt en de bureancratie van de overheid $z i j n$ meer institutionele arrangementen mogelijk, dan de leerboeken ons helaas nog steeds doen geloven (zie echter witgebneid Savas, 1982; 1987). Dat vraagt om "market makers", en dat nier alleen aan de buitenkant van de publieke sector, in verzelfstandigde agentschaps. structuren, zelfstandige bestuursorganen $\left(Z \mathrm{ZOO}^{\circ} \mathrm{s}\right)$ en geprivatiseerde bedrijven, maar ook aan de binnenkant. Dat laatste vraagt ook om "public entrepreneurs", on publiek en maatschappelijk ondernemerschap en om 'Reinventing Government' (zie Osbome and Gaebler, 1993).

\section{Open procesbenadering}

Ten laatste vergt zuks het loslaten van de zogeheten "gesloten programmabenadering" van beleidsprogramma's, ofwel de hierboven gehekelde ingenieursbenadering. In plaats daarvan is een meer 'open procesbenadering' van beleid meer op zujn plats. Als er dan toch nog gepland 
moet worden, past daarbij veel beter de aanpak van 'mixed scanning' (inmiddels kinssiek geworden door het denten van Etzioni, 1991). Daarbij is het de kunst on alle kennis, expertise en creativiteit die in de hoofden van mensen en organisaties zit die deel uitmaken van het beleidsnetwerk, te mobiliseren voor het bedenken en toepassen van nieuwe oplossingen voor prangende problemen. Met zo'n open procesbenadering wordt ook rumte gemaakt voor "beleidsinnovatie' in de publieke sector. Waarom horen wij daar nu zo weinig over? Beleidsimowatie kan althans gedeeltelijk worden georganiseerd en in elk geval gefaciliteerd. Proces- en produktinnowatie is toch niet per definitie alleen voorbehouden an marktorganisaties? Daarvoor is echter wel rumte nodig voor experimenteedust, voor institutionele pluriformiteit en woor beleidsmatige warièteit in de publicke sector (zie Van Mierlo, 1998; 2000). Werschillen en tegenspraak brengen ons verder, niet overeenkomsten en 'koekoekeenzang". Senge's concept (1992) van de "lerende organisatie" (met enkelslag, dubbelslag en zelfs drieslag leren met behulp van de 'fifth discipline') wijst ons hier de weg (zie voor de publieke sector ook Van Mierlo, 1995 a en 1995b).

Mijn conclusie luidi dan ook, dat or wel degelijk lets aan de structurele oorzaken van beleidsfalen kan worden gedaan. Het kan gelukkig ook helemaal anders.

\section{CONSEQUENTIES VOOR DE KERNTAKEN VAN DE UNIVERSITEIT}

Daarmee kom ik aan het laatste onderdeet wan deze oratie. Welka consequenties heeft dat nu allemaal voor de kemtaken van de uniwersiteit, voor onderwijs en onderzoek? In de kern gaat het: om drie dingen: om het grote goed van de academische onafhankelijkheid, om het belang van een "second opinion" en kritische secundaire analyse, en om het aan de kaak stellen van de waan wan de dag en van de keizer die geen kleren aan heeft.

Wetenschappelik onafhankelijheid is het uitgangspunt van elke academische activiteit. Derde geldstroom-onderzoek en -onderwijs zijn van belang als één van de drie inkomensbromen en als toetssteen van de bevrediging van matschappelijke behoeften aan onderwijs en onderzoek. Ook de universiteit is op weg naar een zogeheten "matschappelike onderneming" (zie voor dit begrip De Wal, 2000), met de nadruk op een dynamisch evenwicht tussen beide elementen, tussen ondernemerschap en maatschappelijke behoeften. Dat betekent een. diversificatie van produkt/markt-combinaties in onderwijs en onderzoek. Op die manier blijft er de noodzakelijke ruimte voor de opleiding van kritische, mondige en onaflankelike studenten. Wij leiden immers als faculteit zelf onze toekomstige beleidsmakers, beleidsadviseurs on beleidsonderzoekers in zowel de publieke sector als de particuliere sector op. Van hén zal het in. de toekomst moeten komen voor een andere manier van beleidsvorming. Ook blijft er op die manier ruimte woor niet alleen fundamenteel onderzoek, maar ook toegepast onderzoek op de universiteit, warbij de onderzoeker zich niet hoeft te laten ringeloren, ja prostitueren door een al te dwingende opdrachtgever (zie het geruchmakende boek van Köbben en Tromp, 1999; echter ook Van der $\mathrm{Aa}, 1999 ;$ Lelieveldt, 1999; Groenewegen, 2000). Een academische vrijplats van onderzoek winden wij darom niet alleen terug in departementen en onderzoeksscholen, maar ook in de Wetenschapswinkel die bemiddelt tussen vraag en aanbod van maatschappolijk relewant, maar toch wetenschappelijk onderzoek waarwoor geen koopkrachtige marktvraag is.

Daarmee kom ik uit op het belang van een 'second opinion' on van een fritische secundare analyse van voorgenomen of lopende beleidsprogramma's. Het is toch vreemd dat het wagen wan een "second opinion' in de medische sector een doodnomale zaak is geworden, malar dat dit nog nawwelijks gebeurt in de publieke sector als het gaat om beleidsprogramma's. 
Eenmal ontworpen of lopende beleidsprogrammats zouden heel goed aan een 'second opinion' of een kritische secundare aralyse kuninen worden onderworpen. Zeg maar een extra toetsing aun de hemvraag: kan het betrokken programma de toets der wetenschappelik kritiek doorstaan, kan op grond daarvan een deugdelike woorspelling worden gedaan of het programma ook zal werken? Een dergelijke toetsing van beleidsprogramma's gebeun nog veel te weinig. Weliswaar ligt er het woomemen om bij de Tweede Kamer een zogeheten 'Varificatiebureau' we richten, die tot taak krijgt om angeleverde beleidsinformatie te toetsen op zijn juistheid, ofwel te "verifieren", mar dat bureau is niet onafhankelijk van de Kamer maar daaraan ondergeschikt. Mij is voorts ankel het kader van de "Marktwerking, Deregulering en Wetgevingskwaliteit"operatie (MDW) bekend, warrin nieuwe wetgeving wooraf wordt getoetst aan marktwerkings- en concurrentic-uffecteth. Hier ligt een kans voor de universiteit om ook haar maatschappelijke functie meer gestalte te geven. Ook hier vervult de Wetenschapswinkel en mutige functie, zo weet ik uit eigen ervaring. Maar er liggen meer mogelijkheden. De Algemene Rekenkamer heeft Hier wiet het alleenreht en geen monopolie.

Tenslotte: de waan van de dag en het geltjk van de wismarkt komen miet alleen voor in de marktsector en in de bedrijfikundebedrijfseconomie, waar de ene hype na de andere manggementgoeroe achterna wordt gelopen (vergeef mij, facultaire collega's, ik overdrijf natumijik een beetje!), maar ook bij de overheid, de publicke sector en in de algemene econonie/openbare financiên. Politieke rationaliteit is lets anders dan wetenschappelijke rationaliteit, je politieke gelijk halen is iets anders dan je wetenschappelijk gelijk hebben. Laten wij beide zaken alsjeblieft niet door elkaar halen. Al te vaak blijkt de keizer uitendelijk woh geen kleren aan te hebben en dan moeten er wel degelijk jongetjes zijn, die dat hardop durven te zeggen. Laten wij meer wan dat soort jongetjes (en meisjes naturijk!) opleiden! 
Minheer de Rector Magnificus,

Ik kom toe aan mijn dankwoord.

Het College van Bestuur van de Universiteit Maastricht dank ik voor het in mij gestelde wertrouwen. Dit geldt ook voor de Benoemingsadviescommie en het Departement Algemene Economie, alsmede het Bestuur van de Faculteit der Economische Wetenschappen en Bedrijfskunde, die bij mijn benoeming een belangrijke rol hebben gespeeld. Het doet mij deugd mijn bijdrage aan de verdere ontwikkeling van onderwijs en onderzoek van deze dynamische faculteit te kunnen voortzetten in het ambt van hoogleraar.

Hooggeleerde Van den Doel, beste Hans,

Helaas kon jij op het laatste moment toch niet bij mijn inauguratie aanwezig zijn. Het is alweer wijfentwintig jaar geleden dat jij mij in Nijmegen "onder het mom varn bestuurskunde de beginselen van de economie, in het bijzonder de welvartstheorie" (dat waren jouw eigen woorden!) hebt bijgebracht (zie Van den Doel, 1973; 1975). lk prijs mij gelukkig zo'n leermeester en vriend te mogen hebben gehad. Dankzij jou ben ik econoom geworden en dankzij jou heb ik het gereedschap van de welvaartstheorie aangereikt gekregen. Daarvan heb ik sindsdien steeds gepast gebruik gemaakt, zoals niet alleen mijn publikatielijst, maar hopelijk ook deze oratie heeft laten zien. Het was een bijzondere generatie studenten die door jou daar in Nijmegen in de roerige jaren 1974-1976 werd opgeleid voordat jij naar Amsterdam vertrok, getuige ook het feit dat ik, als ik goed geteld heb, inmiddels de vijfde afgestudeerde van die generatie ben die tot het hoogleraarsambt is geroepen. Ik vind het een eer om als jouw leerling te worden beschouwd en hoop die eer in dit ambt waard te zijn.

\section{Hooggeleerde Van Schendelen, beste Rinus,}

Wij hebben beiden de opkomst en ondergang van de studierichting Politicologie in Rotterdam meegemaakt, jij als hoogleraar en ik als een van je naaste medewerkers. Laten wij nog maar eens vaststellen dat de sluiting van die studierichting in 1986 op instigatie van toenmalig topambtenaar Roel in 't Veld, een schoolvoorbeeld is geweest van de in deze oratie bestreden 'stalinistische besturingsfilosofie'. Daarvan heeft ook de verantwoordelijk bewindsman minister Deetman later zelf gezegd, dat dat eens maar nooit weer was. Van jou heb ik na mijn Nijmeegse ervaringen nog eens een keer geleerd, om standvastig te zijn in zaken die de academische integriteit echt bedreigen en je rug recht te houden. Ook was deze crisis voor mij een faciliteit (!), want dat was voor mij de aanleiding om mijn wetenschappelijke heil buiten de Erasmus Universiteit te zoeken. Dat heil heb ik toen in Maastricht gevonden.

Hooggeleerde Cnossen, beste Sijbren,

In 1977, ik werkte toen nog maar net als jongmaatje bij het Fiscaal-Economisch Instituut van de Erasmus Universiteit, kwam jij van het Internationale Monetaire Fonds naar Rotterdam om hoogleraar Fiscale Economie te worden. Jij was en bent een wan de weinigen met die economisch georiënteerde fiscale leeropdracht in Nederland. Sindsdien zijn onze wegen uit 
elkarar geguan, maar wij zijn wel altid contact met elkaar blijwen houden (bijwoorbeld in het kader van een aio-cursus Fiscale Economie hich in Maastricht in 1996). Ik ben daarom zeer blij dat jy (nog wel op dezelfe datum als ik!) bent benoemd tot hoogleraar in Maastricht, maar dan in de Fiscale Economic. Daamee is voor mij de cirkel rond. Sanien zullen wij niet alleen werken. aan de algemeen-conomische verankering van het onderwis en onderzoek in de Fiscale Economie in Mastricht, maar ook, en dat laatste in nauwe samenwerking met de overige collega's van de Werkgroep Economie van de Publieke Sector, aan de vemieuwing van het vakgebied valu de Openbare Finameiën in onze faculteit. Ilk verheug mij op onze intellectuele en persoonlijke samenwerking.

\section{Beste collega's wan de wetenschappelike en niet-wetenschappelijke sitaf van het Departement Algemene Economic,}

Sinds 1987 verkeer ik in jullic midden. Ook jullie hebben bijgedragen aan mijn vorming tot econoom, al zal ik in jullie ogen altijd wel een "politiek econoom" zijn gebleven. Dat geeft helemaal niet. Van jullie heb ik geleerd dat professionele meningsverschillen heel vruchtbar kumnen zijn voor economisch-wetenschappelijk denken en handelen in onderwijs en onderzoek. Niet overeenkomsten maar verschillen, niet naar de mond praten maar tegenspraak brengt ons immers verder. Laten wij daarom vooral doorgan met de inhoudelijke discussie en darbij onze fundamentele twijtels behouden en niet bezwijken voor de verleiding, die in te ruilen voor onwankelbare schijnzekerheden. IKk hoop onder die onstandigheden ook in de toekomst met jullie te mogen blijven samenwerken an de verdere profilering van de verschillende vakgebieden wan de Algemene Economie binnen onze faculteit.

\section{Beste collega's van de Wetenschapswinkel,}

Al weer zo'n zeven jlaar mag ik vooral economisch studentenonderzoek van jullie winkel begeleiden en ik doe dat zoals jullie hebben gemerkt met veel plezier. Juist de Wetenschapswinkel is cen van die academische vrijplaatsen op onze universiteit, waar maatschappelijk relewant maar ook wetenschappelijk onderzoek wordt verricht zonder directe financiële druk van belanghebbende opdrachtgevers. Hoe belangrijk dat is, heb ik proberen aan te tonen in deze oratie Sinds enkelle jaren ben ik ook voorzitter wan de wetenschappelijke Adviesraad van de Wetenschapswinkel. Ik hoop de komende jaren in beide functies nauw met jullie te mogen blijwen samenwerken. Niet alleen fungeent de Wetenschapswinkel op die manier als onderzoekswerkplaats voor studenten van ook onze faculteit, maar ook leer ik daar zelf nog steeds van.

\section{Besie shidentern,}

Allereerst die in de Algenene Economie, International Economic Studies, Bedrifseconomie, Interitationaal Management en Internationale Bedrijfskunde. Jullie hoop ik niet alleen nog lang een inleiding in het vakgebied Openbare Financièn te kumen geven, maar ook te kumnen laten bliven kennis maken met vragshukken van Public Managentent en van de Fiscaliteit. Voorts ook de studenten Fiscale Economie, voor wie ik als Opleidingsdirecteur een bijzondere verantwoordelijkheid draag, en de studenten Fiscal Recht Zoals jullie al gemerkt hebben ligt mijn hart primair bij jullie. Onderwijs en onderzoek hangen onlosmakelijk met elkarar samen in het takenpakket van een hoogleraar. Ik hoop ook dat ik nog lang wan jullie mag leren. 


\section{Lieve moeder}

Ik ben blij dat $u$ er vandaag ook bij kunt zijn. Dankzij $\mathrm{u}$ en vader heb ik de gelegenheid gekregen om naar het Gymnasium te gaan, de eerste stap op de lange weg naar dit ambt. Dat was zeker voor die tijd, in 1965, nog zeer ongebruikelijk. Ik hoop dat vader en u trots op mij kunnen zijn.

\section{Lieve Wini.}

Tot slot, maar het meest belangrijk: mijn echtgenote, die samen met mij zozeer naar deze dag heeft toegeleefd. Ik dank je woor alles, meer woorden zijn tussen ons niet nodig.

Zeer gewaardeerde toehoorders,

Ik heb gezegd. 



\section{LITERATUUR}

Aa, R. van der, Niet bij brood alleen! Over de binnenkant wan contractonderzoek, in Facta. Sociad wetenschappelijk magazine, laargang 7 nummer 8, December 1999, pp. 12-14.

Algemene Rekenkamer, Beleidsinformatie Betumerowte, Den Haag, juni 2000.

Aquina, H.J., Beleidswetensichap en Wetenschapsbeleid, Nijmegen 1974.

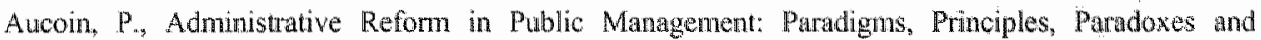
Pendulums, in Govemance: An Mternational Joumal of Policy and Administration, Vol. 3, No. 2 , April 1990, pp. 115-137.

Auerbach, J., and M. Feldstein, (eds.), Handbook of Public Economics, Volume I and II, Amsterdam etc. 1985 .

Bovens, M., and P. "t Hart, Understanding Policy Fiascoes, New Brunswick etc. 1996.

Boyer, K. D. Principles of Transportarion Economics, Reading Mass. 1998.

Brecht, A., Political theory: the foundations of twentieth century political though, Princeton N.J. 1958.

Buchanan, J.M., The Dentand and Supply of Public Goods, Chicago 1968.

Button, KJ., Transport Economics, (second edition). Aldershot 1993.

Centraal Planbureau, Rekeningrijden in de Randstad, Den Haag 1998.

Commission of the European Communities. Evaluation Unit Methods and Instruments for Project Cycle Management, Manual Project Cycle Management. Imtegrated Approach and Logical Franiework, Number 1, Brussels, February 1993.

Doel, J. van den, Ehonomie en Demokrakie in het Statsbestum, Oratie Katholieke Universiteit Nijmegen, Deventer 1973, herdrukt in W. Driehulis, (red.), 197\%, pp. 325-358.

Doel, J. van den. Demokratie en Welwartstheorie, een imbiding in mieuwe politieke ekonomie, (eerste druk), Alphen aan den Rijn 1975.

Driehuis, W., (red.), Economische theorie en economische politiek in discusse, Leider 1977.

Etzioni, A., A Responsive Society: colleched essass on guiding deliberate social change, San Francisco etc. 1991.

Frederickson, HG.; Comparing the Reinventing Govemment Movement with the New Public Administration, in Public Administration Review, Vol, 56, No. 3, May/June 1996, pp. 263-270.

Frissen, P.H.A. en W. van der Meeren, Gezondheidszorg is gebaat bij ontregeling, in de Volkwhon, 20 mei 2000. 
Gasper, Des, Logical frawteworks: a crincal assessment, Working Paper 4264 , hastitute of Social Sudies, The Hague, December 1997.

Goedhart, C., Hoofdlines wan de leer der openbare financiên, (erste druk) 1958, (derde druk), Leiden 1975.

Goodsel: Ch., Reinvemt Government or Rediscover It? in Public Administration Review, Vol. 53, No. 1, January/February 1993 , pp. $85-87$.

Groencwegen, $J$, Blind volgen economische school kan ongezond zijn, in NRC Handelsblad, 20 juli 2000 .

Hague Consulting Group, TRACE. Coss of private road ravel and heir effects on demand, including short and Jong term elasticinies, Research Project for the European Commission, DirectorateGeneral for Trumport. Deliverables I (Review of existing evidence on time and cost clasticities of travel demand and on walue of travel time), 3 (Report on national elasticities), 4 (TRACER: a sketch plaming model), and 5 (Elasticity handbook), Den Haag 1998-1999.

Hall, P, Great Planning Disasters, (first edition), 1980, (second edition), Harmondsworth 1981.

Hayek, F.A., (ed.) $)_{4}$ Collectinist Economic Plonming. Critical Sindies on the Possibilities of Socialsm, (fifth impression), London 1956.

Hayek, F.A., The Roud to Serfom, London 1944.

Herings, P.J.J., Van Alle Markten Thus, Oratic Universiteit Maastricht, Maastricht 2000.

Hirsthman, A.O., Exil, woice and loyaly: responses to decline in firms, organizations and states, Cambridge Mass. 1970.

Hood, Ch., A Public Management for All Sensons?, in Public Administration, Vol. 69, Spring 1991, pp. 3-19.

Hoogerwerf, A, Beleid berust op veronderstellingen; De Beleidstheorie, in Acra Politica, Jaargang 19 nummer 4,1984, pp. $493-531$.

Hoongerwerf, A., (red.), Overheidsbeleid, (vijfde druk), Alphen aan den Rijn 1993.

Hoogerwerf, A., Beleid, processen en eftecten, in A. Hoogerwerf, (red.), 1993, pp. 17-34.

Hoogerwerf, A. (ned), Het ontwerpen wan beleid. Een handleiding woor de praknijk en resultaten wan onderzoek, (tweede druk), Alphen an den Rijn 1998.

Hoogerwerf, $\mathrm{A}_{1}$, Het ontwerpen van beleid als wetenschapstoepassing, in $\mathrm{A}$. Hoogenwerf, (red.), 1998, pp. 13. 34 .

Kobben, A.J.F, en H. Tromp, De onwelkone boodschap, of hoe de wijheid von wetenschap bedreigd word, Amsterdam 1999.

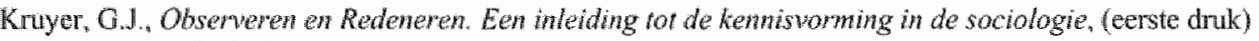
1959. (vijfde druk), Meppel 1986 
Leew, F.L., Assumptional analysis, log frame andysis awd other methods of reconstricting and evaluaring program logic, Working Paper. Netherlands Open University/Utrecht University. Heerlen Utrecht 1999.

LeGrand, I., and W. Bartlet, Qhasi-Markew and Social Policy, Basingstoke and London 1993.

Lelieveldt, J., De onwelkome boodschap. Verslag wan een forumdiscussie, in Facra. Soctack wetenschappelijk magazine, Jaargang 7 nummer 5 . September 1999, pp. 18-21.

Mierlo, J.G.A. van. Spatial Analysis of Electoral Compettion. Demand and Supply or Economic Policy in Representative Democracy; the Netherlands 1946-1982. Delft 1989.

Mierlo, J.G.A. van, Leerprocessen over en weer van Openbaar Bestuur en Ondememingem, Deel 1, Siruchurele Alternatieven?, in J.M.H.J. Hemels en W.L.A. wan Tuyll van Serooskerken, (red), Berwaren en Imnowate: Handboek woor Bestuwrders en Monogers, Houten, Zesde annulling, mei 1995a. pp. B 0700-1-B 0700-14.

Mierlo, J.G.A van, Leerprocessen over ein weer wan Openbaur Bestuur en Ondememingen, Deel 2. Leerprocessen over en weer, in J.M.H.J. Hemels en W.L.A. van Tuyll van Serooskerken, (red.), Besturen en Innovate: Handboek voor Bestwurders en Managers, Houten, Zevende Aanvulling. augustus $1995 \mathrm{~b}$, pp. B0700-15-B $0700-40$.

Mierlo, J.G.A. van, Lessons from the Experience of OECD Countries, in Verhaijen and Coombes, (eds.). 1998, pp. $388-403$.

Mierlo, J.G.A. van, Public Choice. Fiscal Federalism and Institutional Varten in the Public Sector: Lessons for Economies in Transition, Paper presented for the Firsi International Conference on Public Chotce - The Changing Role of Govemment in the Economy, Vitoshen, Bulgaria, March 2000 .

Ministerie van Justitie, Het Pad maar de Achterdew", Den Haag, april 2000.

Ministerie van Verkeer en Waterstaat, Bereikbaarheids Offensief Randstad (BOR), Den Hagg maart 2000.

Ministerie van Verkeer en Waterstaat, Nota naar aanleiding van verslag rekeningrijden. Den Haag. juni 2000.

Ministerie war Verkeer en Waterstaat en Ministerie van Financien, Brief aan Twede Kamer ower Wetswoorstel Rekeningriden, (DGP/M/Rn,990014), Den Haag, 18 juni 2000.

Miron, A.J., and \$. Zwiebel. The Economic Case Against Drigg Prohibition, in Joumat of Ecomomic Perspectives, Volume 9, Number 4, Fall 1995, pp. 175-192.

Musgrave, R.A., A brief history of fiscal doctrine, in Auerbach and Fefdstein, (eds.), Volume I, 1985, pp. 1.59 .

Musgrave, R.A., and P.B. Musgrave, Public Finance in Theory and Practice, (fifth edition), New York etc. 1989.

Musgrawe, R.A., and A.T. Peacock, (eds.), Classics in the Theory of Public Finance, (first edition) 1958, (second edition), Basingstoke and London 1967.

Oort. C.J., Decreasing costs as a problem of weffare ecomomics, Amsterdan 1958. 
Oor, C.J, Optimale vervoersprifzen, in De Economist, Jaurgang 107, 1959, pp. 417-457.

Osbome. D. and T. Gaebler, Reinventing Government: How the Entreprewential Spiri Is Transforning the Public Sector from Schowhouse to Statehouse, City Hall to the Pentagon, Reading Mass. 1993

Ree. E. van, Hoe misvatingen een monster baarden: honderd jaar drugsbestrijding, in Socialisme en Democratie, Jatargang 57 nummer 6,2000, pp. 293-202.

Regeringsnota, Het Nederlandse Drugsbeleid: Continuthet en Verandering, Den Haxg 1997.

Satzinger, F. Camabis Policy in the Netherlands. A Microconowic and Public Choice Anolysis including a Case Study on the City of Maastricht, Rappont Wetenschapswinkel Universiteit Maastricht, Maastricht, April 2000.

Savas, E.S.,Pryantwg the Public Sector. How to Shrim Government, Chatham N.J. 1982.

Savas, E.S. Privatizadion. The Key to Better Government, Chatham N.J. 1987.

Senge, P., The Fifh Discipline: the art and practice of the leawning organization, London etc. 1992.

Solem, R.R., The logical framework approach to project design. Review and evaluation in A.I.D.: genesis, impact, problems, and opporthnities, Working Paper 99, A.I.D., Washington D.C. 1987.

Stiglitz, J.E., Economics of the Public Sector, (third edition), New York and London 2000.

Tinbergen, J., Econowische Bewegingsteer, Amsterdam 1943.

Tinbergen, J.,Economic Policy. Principles and Design, (fourth edition), Amsterdam 1967.

Tromp, B.. Moedwilige deprofessionalisering, in Socialisme en Democratie, Jaargang 49 nummer 4, 1992, pp. $153-156$.

Tullock, G., Rent Seeking, Aldershot 1993.

Veld, R.J. in "t, Noorderlicht, over scheiding en samenballing, 's-Gravenhage 1997.

Veld, R.J. in " ${ }_{1}$ (red.), Sturingswaan en Omtmohtering, Utrecht 1999.

Verheijen. T., and D. Coombes. (eds.), Innovations in Public Management, Parspectives from East and West Europe Cheltenhan UK and Northampton Mass. 1998.

Folkkram, de. "Kanner eist gedoogbeleid voor levering sofidrugs", 28 juni 2000.

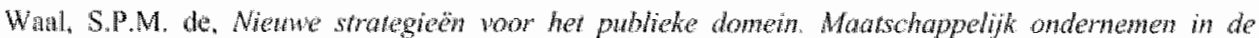
prokrijk. Alphen ann den Rijn 2000.

Walsh, K., Public Services and Market Mechanisms, Competition, Contracting and the New Public Managenewt, Basingstoke and London 1995.

Wit, J.G. de, en H.A. van Gent, Economie on manspon, Utrecht 1996.

Wolf. Cln. Markets or Gowenmenis. Choowing between imperfect ahernatwer, (first edition) 1988, (second dition). Cambridge Mass. 1993. 
Wolfson, D.J., Publieke Sector en Economische Orde, Groningen 1988.

Wolson, D.J. Leren We Het Ooit? Een mehodologische verkenming, als oefering in bescheidenhed. Afscheidscollege Erasmus Universiteit Rotterdam, Deventer 1998.

Zerbe, R.O., and D.D. Dively, Benent-Cost Analysis in Theory and Prowtice, New York 1994. 